University of Miami Law School University of Miami School of Law Institutional Repository

2019

Procompetitive Justifications in Antitrust Law

John M. Newman

Follow this and additional works at: https://repository.law.miami.edu/fac_articles

Part of the Antitrust and Trade Regulation Commons 


\title{
Procompetitive JuSTIFICATIONS In ANTITRUST LAW
}

\author{
JOHN M. NEWMAN ${ }^{*}$
}

The Rule of Reason, which has come to dominate modern antitrust law, allows defendants the opportunity to justify their conduct by demonstrating procompetitive effects. Seizing the opportunity, defendants have begun offering increasingly numerous and creative explanations for their behavior.

But which of these myriad justifications are valid? To leading jurists and scholars, this has remained an "open question," even an "absolute mystery." Examination of the relevant case law reveals multiple competing approaches and seemingly irreconcilable opinions. The ongoing lack of clarity in this area is inexcusable: procompetitive-justification analysis is vital to a properly functioning antitrust enterprise.

This Article provides answers and clarity. It identifies the market failure approach to analysis as doctrinally correct and economically optimal. The leading alternatives pose an unacceptably high risk of error, in the form of both false positives and false negatives. Most importantly, the Article identifies the proper, three-step method for assessing procompetitive justifications. This three-step analytical framework increases transparency and rigor, minimizes errors, and maximizes welfare.

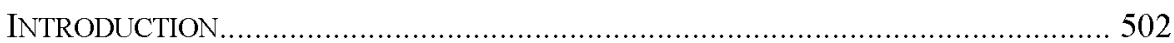

I. Procompetitive Justifications: Competing APPROACHES ..................... 506

A. MARKET FAILURE ............................................................... 509

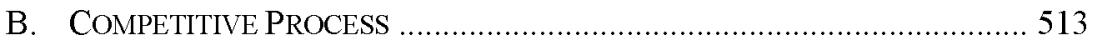

C. TYPE OF EFFECT .................................................................... 516

II. DOCTRINAL BASIS FOR THE MARKET-FAILURE APPROACH ....................... 517

A. EARLY SUPPORT .................................................................. 518

B. The Competitive Process ERA ............................................... 519

C. THE MODERN ERA.............................................................. 522

D. ASSESSING NON-WELFARE “JUSTIFICATIONS" ............................... 526

III. ERROR-COST ANALYSIS....................................................................... 530

A. COMPETITIVE PROCESS: IMPRECISION AND FALSE POSITIVES ............. 531

B. TYPE OF EFFECT: IMPRECISION, FALSE POSITIVES, AND FALSE NEGATIVES ......................................................... 534

* Assistant Professor, University of Memphis Cecil C. Humphreys School of Law. For their insightful comments on and critiques of earlier drafts, I owe a debt of gratitude to Herbert Hovenkamp, Rebecca Haw Allensworth, Alan Meese, Mark Patterson, Shubha Ghosh, Daniel Sokol, Harry First, Jonathan M. Jacobson, Michael Jacobs, Julian Nowag, Susan Musser, Matthew Sipe, Shi-Ling Hsu, Chapin Cimino, Joshua M. Silverstein, Stephanie Bair, and Gregory Werden, as well as participants at the 18th Annual Antitrust Colloquium at the Loyola University (Chicago) School of Law, the 2018 New York University/American Bar Association Next Generation of Antitrust Scholars Conference, and the 2017 Midwestern Law \& Economics Association Annual Conference. Thanks also to Devon C. Muse, Hayden D. Carlson, and Sean O'Brien for providing outstanding research assistance. 
C. The MARKET-F AILURE APPROACH MinimiZES ERrors ..................... 538

IV. ANALYZING PROCOMPETITIVE JUSTIFICATIONS ............................... 540

A. THE THREE-STEP FRAMEWORK ............................................... 540

B. CASE COMPARISON: INCREASING RIGOR, IMPROVING OUTCOMES ....... 542

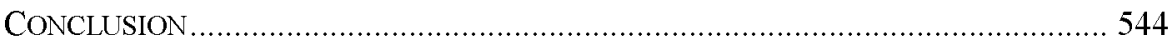

"That's always been an absolute mystery to put to the class...." - Justice Stephen Breyer ${ }^{1}$

\section{INTRODUCTION}

The Rule of Reason has come to dominate antitrust law. ${ }^{2}$ Over the past several decades, courts have systematically retreated from bright-line rules condemning various categories of marketplace conduct as per se illegal. ${ }^{3}$ The Rule of Reason, a more searching mode of analysis, takes into account both harmful and beneficial effects of defendants' conduct. ${ }^{4}$ For decades, what qualifies as "harmful" has been the subject of intense judicial and scholarly debate. ${ }^{5}$ But what counts as "beneficial"?

Analyzing beneficial effects, or, in modern parlance, "procompetitive justifications," is a vital cornerstone of modern antitrust jurisprudence. But it is also a topic that remains-particularly in light of its importance-rather shockingly

1. Transcript of Oral Argument at 24, Ohio v. Am. Express Co., 138 S. Ct. 2274 (2018) (No. 16-1454).

2. Phillip E. Areeda \& Herbert Hovenkamp, Antitrust law: An Analysis of ANTITRUst PRINCIPLES AND Their ApPLICATION 1 1500, at 388 (4th ed. 2017) ("Ever since [the U.S. Supreme Court's 1911 Standard Oil decision], antitrust law has been governed predominantly by a "rule of reason." "). Analysts tend to use the term "rule of reason" to describe Sherman Act $\S 1$ proceedings, though the structural framework is similar to merger and monopoly analyses. The present discussion generally confines itself to Sherman Act $\S 1$, but the implications offer value in merger and monopolization contexts as well. See generally Andrew I. Gavil, Moving Beyond Caricature and Characterization: The Modern Rule of Reason in Practice, 85 S. CAL. L. Rev. 733, 735 (2012) (describing modern antitrust as "a collection of 'rules of reason' that cut across [statutes] and serve as a set of unifying first principles of antitrust law').

3. See, e.g., Gavil, supra note 2, at 734 ("The rule of reason has evolved considerably . .. , largely due to the Court's . . march away from per se rules and undemanding burdens of proof.").

4. See, e.g., Rebecca Haw Allensworth, The Commensurability Myth in Antitrust, 69 VAND. L. REV. 1, 5 n.7 (2016) ("The Rule of Reason ... [is] a standard that balances pro- with anticompetitive effects ...."). But see Michael A. Carrier, The Real Rule of Reason: Bridging the Disconnect, 1999 BYUL. REv. 1265 (finding that actual balancing is quite rare); D. Daniel Sokol, The Transformation of Vertical Restraints: Per Se Illegality, the Rule of Reason, and Per Se Legality, 79 ANTITRUst L.J. 1003, 1008 (2014) (arguing that some types of vertical restraints have effectively become per se legal).

5. Neither Congress nor the U.S. Supreme Court have clearly articulated the goal $(\mathrm{s})$ of antitrust law, prompting a long-running academic debate. See, e.g., Roger D. Blair \& D. Daniel Sokol, The Rule of Reason and the Goals of Antitrust: An Economic Approach, 78 ANTITRUST L.J. 471, 473 (2012). 
underexplored. Justice Breyer's "absolute mystery" quip was made in February 2018, some forty years after antitrust supposedly entered its "Modern Era." ${ }^{\text {L }}$ Leading scholars agree: "what constitutes an offsetting benefit to competition" remains a "question left open." An examination of the relevant case law reveals competing approaches that have produced seemingly irreconcilable results. The resulting confusion is such that different analysts can view the very same U.S. Supreme Court decision as both a "conundrum" and also the "most elucidating" opinion on the subject.

Meanwhile, modern antitrust defendants have continued to offer an everexpanding plethora of justifications for their conduct. In recent years, defendants have attempted to avoid liability by arguing variously that their restraints of trade created a "healthier market" by facilitating the launch of an online e-book platform, ${ }^{10}$ preserved "amateurism" and promoted "competitive balance" in college sports, ${ }^{11}$ promoted the "health and welfare" of horses ${ }^{12}$ helped pay for "uniforms and newly painted trucks," ${ }^{13}$ integrated college academics and athletic programs, ${ }^{14}$ responded to an "inherently anticompetitive" government-agency action, ${ }^{15}$ increased access to Ivy League colleges for financially needy students, ${ }^{16}$ promoted student-body diversity, ${ }^{17}$ enhanced the defendant's "market penetration," ${ }^{18}$ helped to limit conflicts of interest among employees, ${ }^{19}$ ensured the "undivided loyalty" of National Football League team owners,${ }^{20}$ helped to fund cemeteries' task of resetting grave memorials that "have settled or shifted," 21 and many more.

Defendants have even argued that two polar opposite effects were both procompetitive. A hospital has argued that it needed to prevent one group of

6. Transcript of Oral Argument at 24, Am. Express Co., 138 S. Ct. 2274 (No. 16-1454).

7. Lawrence A. Sullivan, Warren S. Grimes \& Christopher L. Sagers, The Law of Antitrust: An InTEGRated HandBook $\S 5.3 \mathrm{f}$, at 223 (3d ed. 2016).

8. Id.

9. Gregory J. Werden, Antitrust's Rule of Reason: Only Competition Matters, 79 ANTITRUst L.J. 713, 732 (2014).

10. United States v. Apple, 952 F. Supp. 2d 638, 707-08 (S.D.N.Y. 2013), aff'd, 787 F.3d 131 (2015) ("Censuring Apple for entering a tumultuous new market, in Apple's view, will have a 'chilling and confounding ... effect not only on commerce but specifically on content markets throughout this country.' . . It is not entirely clear to what Apple is alluding, however, when it describes its pro-competitive behavior and creation of healthy competition.").

11. O'Bannon v. NCAA, 802 F.3d 1049, 1058 (9th Cir. 2015).

12. JES Props., Inc. v. USA Equestrian, Inc., No. 8:02-CV-1585 T24MAP, 2005 WL 1126665 , at *16 (M.D. Fla. May 9, 2005).

13. New York v. Anheuser-Busch, Inc., 811 F. Supp. 848, 876 (E.D.N.Y. 1993).

14. O'Bannon, $802 \mathrm{~F} .3 \mathrm{~d}$ at 1058.

15. United States v. N.D. Hosp. Ass'n, 640 F. Supp. 1028, 1039 (D.N.D. 1986).

16. United States v. Brown Univ., 5 F.3d 658, 674 (3d Cir. 1993).

17. $I d$.

18. Graphic Products Distribs., Inc. v. Itek Corp. 717 F.2d 1560, 1578 (11th Cir. 1983).

19. Pluekhahn v. Farmers Ins. Exch., 749 F.2d 241, 245 (5th Cir. 1985).

20. N. Am. Soccer League v. NFL, 670 F.2d 1249, 1261 (2d Cir. 1982).

21. Rosebrough Monument Co. v. Mem'1 Park Cemetery Ass'n, 666 F.2d 1130, 1136 (8th Cir. 1981) 
customers from subsidizing another group ${ }^{22}$ - and a credit card company has argued that it needed to force one group of customers to subsidize another group. ${ }^{23}$ In the face of this chaos, and without clear guidance, judicial decision-making has sometimes floundered.

This Article answers the open questions posed by procompetitive justifications. It begins, in Part I, by identifying and describing the three primary competing approaches to justification analysis. Under the "market failure" approach, a valid justification is present if, and only if, the challenged restraint alleviates a market failure, thereby increasing consumer welfare. ${ }^{24}$ This inquiry is fundamentally consequentialist; it reflects the focus on marketplace effects that is the hallmark of antitrust law's Modern Era. At the same time, it manages to avoid the unhealthy obsession with particular types of effects—output and, to a lesser extent, price—that too often dominate modern antitrust discourse..$^{25}$

The two alternatives to the market-failure approach are the "competitive process" and "type of effect" approaches. Both have been employed by (some) courts; both have attracted a number of leading scholarly advocates and adherents. But, as this Article demonstrates, both of these alternatives are out-of-step doctrinally — and for

22. United States v. N.D. Hosp. Ass'n, 640 F. Supp. 1028, 1038 (D.N.D. 1986).

23. United States v. Am. Express Co., 88 F. Supp. 3d 143, 225 (E.D.N.Y. 2015), rev'd, 838 F.3d 179 (2d Cir. 2016).

24. See infra Section I.B (detailing the doctrinal support for the market-failure approach). This Article is not the first to argue that alleviating a market failure should qualify as a valid procompetitive justification. See Thomas L. Greaney, Quality of Care and Market Failure Defenses in Antitrust Health Care Litigation, 21 ConN. L. REv. 605 (1989) (arguing that market failures may sometimes justify restraints in healthcare markets); Peter J. Hammer, Antitrust Beyond Competition: Market Failures, Total Welfare, and the Challenge of Intramarket Second-Best Tradeoffs, $98 \mathrm{MICH}$. L. REV. 849 (2000) (arguing that restraints are sometimes justified as "intramarket second-best tradeoffs"); Marina Lao, Discrediting Accreditation?: Antitrust and Legal Education, 79 WASH. U. L.Q. 1035, 1083 (2002) (arguing that accreditation decisions may be justified by virtue of curing certain market failures, specifically information asymmetries and externalities); Alan J. Meese, In Praise of All or Nothing Dichotomous Categories: Why Antitrust Law Should Reject the Quick Look, 104 GEO. L.J. 835, 849-50 (2016) (arguing that "technological efficiencies or overcoming a market failure" can trigger rule-of-reason analysis). This Article expands upon past commentary by more clearly identifying and explaining the alternative approaches to procompetitivejustification analysis, making an explicitly doctrinal case for the market-failure approach, and incorporating the Neo-Chicagoan error-cost framework into a normative, consequentialist argument in favor of the market-failure approach. On error-cost analysis and antitrust, see generally Frank H. Easterbrook, The Limits of Antitrust, 63 TEX. L. REv. 1 (1984).

25. The modern consensus is that antitrust should seek to maximize the economic conception of consumer welfare. See, e.g., Leegin Creative Leather Prods., Inc. v. PSKS, Inc., 551 U.S. 877, 889-90 (citing with approval the Brief for the United States as Amicus Curiae Supporting Petitioner, Leegin Creative Leather Prods., Inc. v. PSKS, Inc., 551 U.S. 877, 889 (2007) (No. 06-480) (arguing in favor of relaxing the per se illegality rule against vertical minimum resale-price maintenance on the grounds that such arrangements "may promote interbrand competition and consumer welfare in a variety of ways")); Blair \& Sokol, supra note 5 . The present discussion proceeds under that assumption, without weighing in on whether it is, in fact, correct. 
good reason, since both produce unnecessarily high risks of erroneous decisionmaking.

Part II undertakes a doctrinal analysis of the U.S. Supreme Court's major procompetitive-justification decisions. It identifies some surprisingly early support for the market-failure approach in Justice Brandeis's seminal Chicago Board of Trade opinion ${ }^{26}$ For a brief span of about two decades stretching from 1958 to 1977, however, the Court focused instead on the vague concepts of "competition itself" and the "competitive process." 27 But after this brief dalliance, the Court returned to the market-failure approach, which it has employed ever since ${ }^{28}$

Part II concludes by exploring the normative implications of this doctrinal analysis for "non-welfare justifications." What, for example, is a lower court to make of a defendant's claim that its restraint was necessary to promote horses' health ${ }^{29}$ or increase access to Ivy League education ${ }^{30}$ As a doctrinal matter, such justifications may be considered at a preliminary stage of analysis: they may indicate that a defendant's conduct was truly "noncommercial" and therefore outside the scope of the antitrust laws. But these are not cognizable procompetitive justifications. The scattered judicial decisions recognizing them as such do so erroneously, eroding the value offered by a coherent, workable, and predictable body of antitrust rules.

Part III undertakes an error-cost analysis of the three leading approaches: market failure, competitive process, and type of effect. Of the three, the market-failure approach offers the clearest guidance to stakeholders. It also helpfully (re)focuses antitrust on its consensus goal of promoting consumer welfare. The competitiveprocess and type-of-effect approaches, on the other hand, tend to produce uncertainty, imprecision, and excessive errors.

Building on these insights, Part IV explains how best to analyze procompetitive justifications. The market-failure approach, when employed properly, entails three distinct steps. First, a defendant must identify some specific market failure. Second, the defendant must demonstrate that, absent the challenged restraint, the relevant market actually exhibited (or would have exhibited) the alleged failure. Third, the defendant must show that its restraint actually alleviated the market failure.

As Part IV demonstrates via a real-world case comparison, this three-step framework can help to reduce confusion, increase judicial efficiency, and filter out baseless justifications. ${ }^{31}$ The market-failure approach itself is doctrinally correct and economically optimal. But if it is applied without rigor, it will fail to serve its intended purpose. With the means and ends of modern antitrust enforcement coming under ever-increasing criticism, ${ }^{32}$ the task at hand is of utmost importance to the continuing legitimacy of the antitrust enterprise.

26. See infra Section II.A.

27. See infra Section II.B.

28. See infra Section II.C.

29. JES Props., Inc. v. USA Equestrian, Inc., No. 8:02-CV-1585 T24MAP, 2005 WL 1126665 (M.D. Fla. May 9, 2005).

30. United States v. Brown Univ., 5 F.3d 658, 674 (3d Cir. 1993).

31. See infra Part IV.B (comparing and contrasting United States v. Am. Express Co., 88 F. Supp. 3d 143, 224 (E.D.N.Y. 2015), rev'd, 838 F.3d 179 (2d Cir. 2016), with SCFC ILC, Inc. v. Visa U.S.A., Inc., 36 F.3d 958, 964 (10th Cir. 1994)).

32. See, e.g., Brian Beutler, How Democrats Can Wage War on Monopolies - and Win, 


\section{Procompetitive Justifications: COMPETING APPROACHES}

There is general consensus as to the structure of modern Rule of Reason analysis, within which procompetitive justifications (or the lack thereof) come into play at two distinct stages. ${ }^{33}$ But, despite their prominent role in antitrust enforcement, procompetitive justifications have remained underexplored and poorly understood. At best they pose an "open question"; 34 at worst they represent an "absolute mystery." 35

As an initial, and uncontroversial, matter, not all restraints of trade are condemned by antitrust law. The leading treatise rightly points out that "[i]t is obviously not the purpose of the antitrust laws to condemn collaborations producing socially desirable results." ${ }^{36}$ At a high level, the task of antitrust tribunals and enforcers is to distinguish anticompetitive ("unreasonable") restraints from procompetitive or neutral ("reasonable") restraints. ${ }^{37}$ Only the former are to be condemned under the antitrust laws.

Procompetitive justifications play a two-fold role in this analysis. ${ }^{38}$ First, courts confronting claims under Sherman Act $\S 1$ must decide whether to apply the per se illegality rule or the rule of reason. If the challenged conduct is treated as per se illegal, the plaintiff need not define a relevant market, prove that the defendant has

NEw RePuBLIC (Sept. 16, 2017), https://newrepublic.com/article/144675/democrats -elizabeth-warren-can-wage-war-monopolies-and-win [https://perma.cc/2KRV-2APQ] ("Reformers argue that ... even increased enforcement under the existing legal paradigm would be inadequate because the consumer welfare standard is too narrowly drawn to effectively mitigate the harms of consolidation in the modern age."); David Dayen, The Rehabilitation of Antitrust, AM. PRospect (Dec. 22, 2017), http://prospect.org/article/rehabilitation-antitrust [https://perma.cc/3WRC-7TKP] (describing an "extraordinary hearing" held by the Senate Judiciary Committee over whether the consumer welfare standard remains appropriate); David McLaughlin, Forget Consumer Welfare. This Antitrust Movement Targets Power Instead, BloOMBERG (Jan. 17, 2018, 4:00 AM), https://www.bloomberg.com/news/articles/2018-01-17/forget-consumer-welfare-this-

antitrust-movement-targets-power-instead [https://perma.cc/4V53-AF6U] ("Today, with mounting evidence of increased concentration and declining competition across the economy, a small group of policy wonks is mounting an attack on corporate consolidation. . . Their criticism is sparking fresh debate in Washington and some soul-searching in the insular, nerdy world of competition policy.").

33. That said, even here there is some disagreement-the U.S. Supreme Court, for example, has suggested that the analytical framework does not rise even to the level of a "spectrum." Cal. Dental Ass'n. v. FTC, 526 U.S. 756, 780 (1999).

34. Sullivan ET AL., supra note 7.

35. Transcript of Oral Argument at 24, Ohio v. Am. Express Co., 138 S. Ct. 2274 (2018) (No. 16-1454).

36. AREEDA \& HoveNKAMP, supra note $2,-1504$, at 414.

37. See, e.g., Gavil, supra note 2, at 735 ("The various frameworks of the new rules of reason are all animated by a common purpose: to differentiate anticompetitive from efficient conduct.").

38. For ease of discussion, this Article refers only to per se treatment and the full-scale rule of reason. According to the U.S. Supreme Court, however, "our categories of analysis of anticompetitive effect are less fixed than terms like 'per se,' 'quick look,' and 'rule of reason."” Cal. Dental Ass'n., 526 U.S. at 779. 
market power, or demonstrate actual harmful effects. ${ }^{39}$ Moreover, the defendant cannot offer offsetting procompetitive justifications. ${ }^{40}$ The fact of the conduct alone triggers liability.

The rule of reason (what the leading treatise calls "full-scale rule of reason") ${ }^{41}$ is far less friendly to plaintiffs. ${ }^{42}$ Under this rule, the plaintiff must prove actual or likely effects, market power, or both ${ }^{43}$ If the plaintiff succeeds, the defendant gets a chance to prove offsetting procompetitive justifications. ${ }^{44}$ If the defendant does so, "the burden shifts back to the plaintiff to demonstrate that the procompetitive efficiencies could be reasonably achieved through less anticompetitive means." 45

Thus, this initial choice between per se illegality and the rule of reason is of utmost practical importance. But how is the choice to be made? Courts, enforcers, and commentators often invoke a categorical approach based on the type of conduct at issue. ${ }^{46}$ For example, one often encounters statements to the effect that "horizontal price fixing is per se illegal." ${ }^{47}$ But that is not always true. In the seminal $B M I$ case, for example, the U.S. Supreme Court applied the rule of reason to a joint-licensing arrangement that involved horizontal price fixing because of the agreement's obvious

39. See, e.g., United States v. Socony-Vacuum Oil Co., 310 U.S. 150, 224 n.59 (1940) ("[A] conspiracy to fix prices violates $\S 1$ of the [Sherman] Act though no overt act is shown, though it is not established that the conspirators had the means available for accomplishment of their objective, and though the conspiracy embraced but a part of the interstate or foreign commerce in the commodity.").

40. See id. ("Whatever economic justification particular price-fixing agreements may be thought to have, the law does not permit an inquiry into their reasonableness.").

41. AREEDA \& HovENKAMP, supra note 2, 1504, at 414.

42. Empirical analysis suggests that the rule of reason-as it is currently applied-is essentially fatal to plaintiffs' claims. See Michael A. Carrier, The Rule of Reason: An Empirical Update for the 21st Century, 16 GEO. MASON L. REV. 827, 830 (2009) (finding that, over a ten-year period, defendants won 221 of 222 reported rule of reason cases). At least in litigation scenarios, the modern rule of reason is quite close to becoming a per se legality rule.

43. See, e.g., Ohio v. Am. Express Co., 138 S. Ct. 2274, 2284 (2018) ("[T]he plaintiff has the initial burden to prove that the challenged restraint has a substantial anticompetitive effect that harms consumers in the relevant market.").

44. See id. ("If the plaintiff carries its burden, then the burden shifts to the defendant to show a procompetitive rationale for the restraint.").

45. Id. Other courts have stated that the final step requires the court to balance pro- against anticompetitive effects. E.g., United States v. Microsoft Corp., 253 F.3d 34, 59 (D.C. Cir. 2001) (identifying balancing as the final step of analysis).

46. This was so particularly during the Inhospitality Era. See, e.g., Gavil, supra note 2, at 736 ("[T]he[] modern rule[] of reason also tend[s] to rely far less on the traditional approach of 'categorization' followed by condemnation or exoneration. For at least fifty years, from United States v. Trenton Potteries Co. to Sylvania, the Supreme Court developed a sorting framework that separated antitrust cases into categories based on the nature of the conduct and two distinct rules: per se and rule of reason."). That said, this approach still manifests with some frequency today. See supra notes 32-34 and accompanying text.

47. See, e.g., Identifying Sherman Act Violations, U.S. Attorneys' Manual, U.S. DOJ, https://www.justice.gov/jm/antitrust-resource-manual-2-antitrust-division-field-offices [https://perma.cc/CFC7-ZQL7]. 
beneficial effects. ${ }^{48}$ Other courts have similarly applied the rule of reason to categories of conduct often spoken of as being per se illegal. ${ }^{49}$

As these cases indicate, it is often the presence or absence of plausible procompetitive justifications - not the category of conduct at issue-that drives the choice between the per se rule and the full-scale rule of reason. This is the first function played by procompetitive justifications: courts take an initial glance ${ }^{50}$ at the challenged restraint, ascertain its plausible competitive effects, and decide which rule to apply. ${ }^{51}$ This initial glance can be usefully thought of as "step zero" of the analysis. ${ }^{52}$ At this stage, the procompetitive-justifications inquiry operates purely as a sorting mechanism. ${ }^{53}$

The second function played by procompetitive justifications (or lack thereof) comes into play if the restraint receives full-scale rule of reason analysis, and the plaintiff successfully makes out its prima facie case. Under such circumstances, defendants may proffer procompetitive justifications as a responsive defense. ${ }^{54}$ In a given case, the plaintiff can carry its initial burden by alleging and proving that the challenged conduct "is of a type reasonably calculated to have," ${ }^{55}$ or actually has, ${ }^{56}$ anticompetitive effects. Should the plaintiff do so, the burden of production ${ }^{57}$ shifts to the defendant to identify a valid procompetitive justification for its restraint. ${ }^{58}$

48. Broad. Music, Inc. v. CBS, Inc., 441 U.S. 1 (1979); see also O'Bannon v. NCAA, 802 F.3d 1049 (9th Cir. 2015) (applying the rule of reason to horizontal price-fixing of wages); Nat'1 Bancard Corp. v. Visa U.S.A., Inc., 779 F.2d 592 (11th Cir. 1986) (upholding a uniform interchange fee set by an association of credit card-issuing banks).

49. See, e.g., Polk Bros., Inc. v. Forest City Enters., Inc., 776 F.2d 185 (7th Cir. 1985) (horizontal product-market allocation); United States v. Kemp \& Assocs., Inc., No. 2:16CR403 DS, 2017 WL 3720695 (D. Utah Aug. 28, 2017) (horizontal customer allocation), rev'd on other grounds, No. 17-4148, 2018 WL 5623925 (10th Cir. Oct. 31, 2018).

50. One hesitates to use the term "quick look," given its unique connotations in the antitrust arena. See AREEDA \& HoveNKAMP, supra note 2, $\uparrow 1508$, at 455 ("This treatise has generally avoided using the term 'quick look' unless quoting from decisions, because it suggests a tripartite division ["rule of reason," "quick look," and "per se"] that does not account for the full range of variations that the cases display.").

51. Thus, even the nominal per se rule allows consideration of legitimate justifications that, if found, trigger a full-scale rule of reason inquiry. $I d$. $\uparrow 1504 \mathrm{e}$, at 427 .

52. See Matthew G. Sipe, The Sherman Act and Avoiding Void-for-Vagueness, 45 FLA. ST. U. L. REV. 709, 725 (2018).

53. See, e.g., cases cited supra note 48.

54. See, e.g., United States v. Microsoft Corp., 253 F.3d 34 (D.C. Cir. 2001) (employing a burden-shifting analysis under both Sherman Act $\S 1$ and $\S 2$, identifying balancing as the final step of analysis).

55. AREEDA \& HoveNKAMP, supra note $2,1504 \mathrm{~b}$, at 415.

56. FTC v. Ind. Fed'n of Dentists, 476 U.S. 447, 457 (1986); Microsoft, 253 F.3d at 5859.

57. See, e.g., Alan J. Meese, Price Theory, Competition, and the Rule of Reason, $2003 \mathrm{U}$. ILL. L. REV. 77, 108.

58. Despite some doctrinal confusion, most authorities agree that if the defendant establishes a procompetitive justification, the next stage entails examining whether lessrestrictive means were available. C. Scott Hemphill, Less Restrictive Alternatives in Antitrust Law, 116 Colum. L. REV. 927, 938 n.49 (2016) (collecting cases). Absent such an alternative, the majority view is that courts will balance the anticompetitive effects against the 
The following discussion identifies and describes the three leading alternative approaches to assessing procompetitive justifications at these two stages of antitrust analysis. Each approach has been used at various times, and with varying degrees of success, by antitrust courts and enforcers. ${ }^{59}$

\section{A. Market Failure}

At a high level, the market-failure approach asks whether a defendant's conduct alleviated a failure, or inefficiency, of the relevant market. As this Article will demonstrate, the market-failure approach is doctrinally correct and produces superior outcomes with lower attendant error costs relative to the alternative approaches. To set the groundwork, a brief primer on the workings and underlying economics of the market-failure approach follows.

Because analyzing all of the interactions in an economy ("general equilibrium analysis") is not practical, antitrust analysts instead employ "partial equilibrium analysis." ${ }^{\prime \prime 0}$ This methodology entails defining and analyzing a single market-the "relevant market"61 - in isolation, holding constant competitive conditions in all other markets. ${ }^{62}$

A market failure occurs when the relevant market produces outcomes that are less efficient than they might be. ${ }^{63}$ As employed in antitrust law and economics,

procompetitive effects. E.g., Microsoft, 253 F.3d at 58-59; Carrier, supra note 4.

59. The literature identifies additional approaches that have not met with as much acceptance from courts and enforcers. See, e.g., Thomas J. Horton, Efficiencies and Antitrust Reconsidered: An Evolutionary Perspective, 60 ANTITRUST Bull. 168 (2015) (identifying the redundancy and antifragility of small units relative to large ones as a type of efficiency).

60. See, e.g., Hammer, supra note 24, at 853-56.

61. "Relevant market" is a term of art in antitrust, the legal significance of which can be, in a given case, somewhat murky. In some cases-for example, those involving hardcore horizontal price fixing without any plausible procompetitive justifications - plaintiffs are not required to prove that the defendants possessed market power, which usually requires first defining a "relevant market." See, e.g., Louis Kaplow, Why (Ever) Define Markets?, 124 HARV. L. REV. 437, 438-39 (2010) (noting that market definition plays a "roughly similar" role in competition law regimes outside the United States). But in many-perhaps most-civil antitrust cases, market definition plays a pivotal role. See id. at 439 (citing Eastman Kodak Co. v. Image Technical Servs., Inc., 504 U.S. 451, 469 n.15 (1992) ("Because market power is often inferred from market share, market definition generally determines the result of the case.")).

62. Hammer, supra note 24 , at 856 .

63. See generally, e.g., Dennis W. Carlton \& Jeffrey M. Perloff, Modern INDUSTRIAL ORGANIZATION 122(1990) (referring to "distortions" like externalities as "market failures"); Francis M. Bator, The Anatomy of Market Failure, 72 Q.J. ECON. 351, 351 (1958) ("What is it we mean by "market failure'? Typically, ... we mean the failure of a more or less idealized system of price-market institutions to sustain 'desirable' activities or to estop 'undesirable' activities."). The law and economics literature postdating the Great Recession offers relatively nuanced discussion of market failure. See, e.g., Robert A. Brown, Financial Reform and the Subsidization of Sophisticated Investors 'Ignorance in Securitization Markets, 7 N.Y.U. J.L. \& Bus. 105, 145 (2010) ("The term market failure is a term of art in economics.

[E]conomists frequently disagree about the definition of the term . . . ."); Gabriel Rauterberg, The Corporation's Place in Society, 114 Мich. L. REv. 913, 914-15 (2016) 
"efficiency" generally refers to "Kaldor-Hicks" efficiency. ${ }^{64}$ A change is KaldorHicks efficient if those made better off thereby could compensate (out of their gains) any left worse off. ${ }^{65}$ How are terms like "better" and "worse" defined? In this context, they relate to "welfare," a sometimes frustratingly vague signifier properly synonymous with the price-theoretic concept of "surplus," 66 the difference between what a buyer (or seller) would have been willing to pay (or accept) and what that buyer actually paid (or accepted) ${ }^{67}$ More specifically, then, an antitrust market failure occurs where the relevant market could better promote surplus.

But whose surplus? An academic debate still lingers over which market participants' surplus is relevant to antitrust analysis. Proponents of a total- or socialwelfare standard contend that both producer and consumer surplus are relevant, whereas consumer welfare advocates focus solely on consumer surplus. ${ }^{68}$ In practice, courts seem to prefer a consumer welfare standard ${ }^{69}$ suggesting that only restraints of trade that increase consumer surplus are potentially justified. If a restraint increases a monopolist's surplus but decreases consumer surplus, it will likely be condemned - even if the monopolist's gain from the restraint is so large that it could have hypothetically compensated consumers' losses.

Where a market fails to maximize consumer welfare as well as it otherwise might, it is—in the argot of antitrust courts—not "efficient." "It has become commonplace

(defining "market failure" as occurring "when the allocation of goods and services in a market is inefficient for some reason"); Steven L. Schwarcz, The Governance Structure of Shadow Banking: Rethinking Assumptions About Limited Liability, 90 NotRE DAME L. REv. 1, 15 (2014) (identifying five "general categories of market failures," including information failure, agency failure, externalities, noncompetitive markets, and public goods problems). Although, as Brown suggests, there is no small amount of disagreement on what constitutes a "market failure," the term is generally understood to denote something less severe than a layperson might assume - a total failure or absence of market activity. See Brown, supra, at 145. Instead, it commonly denotes a market that is operating "inefficiently" relative to some normatively desired benchmark. $I d$. And in the case of antitrust, the modern consensus favors a standard economic conception of "consumer welfare" as the appropriate benchmark.

64. On Kaldor-Hicks versus Pareto optimality, see generally RichARD A. POSNER, ECONOMIC ANAL YSIS OF LAW 12-13 (7th ed. 2007) ("[W] hen an economist says that free trade or competition or the control of pollution or some other policy or state of the world is efficient, nine times out of ten he means Kaldor-Hicks efficient.").

65. E.g., Herbert Hovenkamp, Federal Antitrust Policy: The Law of Competition AND Its PRACTICE $\$ 2.3$, at 101 (5th ed. 2016).

66. Hammer, supra note 24, at 891-95 (discussing consumer surplus and its relationship to total welfare).

67. Id. at 891 .

68. See, e.g., Jonathan B. Baker \& Steven C. Salop, Antitrust, Competition Policy, and Inequality, 104 GEO. L.J. ONLINE 1, 15 (2015).

69. See, e.g., Herbert Hovenkamp, Implementing Antitrust's Welfare Goals, 81 FordHAM L. REV. 2471, 2476 (2013).

70. See, e.g., Leegin Creative Leather Prods., Inc. v. PSKS, Inc., 551 U.S. 877, 902 (2007). The Leegin majority, assessing whether to overrule the decades-old per se prohibition on minimum resale price maintenance (RPM), noted that some alternative strategies could allow a manufacturer to attain the same "procompetitive benefits" as minimum RPM. Yet, per the majority, those strategies "could be less efficient" (emphasis added)-thus, forcing firms to adopt them "hinders competition and consumer welfare because manufacturers are forced 
to speak of "efficiency" as if it were an end unto itself." But efficiency is meaningless in a vacuum: "efficient" at doing what? In modern antitrust discourse, analysts most often mean efficient at promoting consumer welfare. Thus, judicial references to "efficiency" are best understood vis-à-vis a market's impact, beneficial or detrimental, on consumer welfare.

Some restraints of trade imposed by private market participants can improve the relevant market's performance, yielding more efficient outcomes. ${ }^{72}$ In other words, such restraints alleviate a market failure. This concept is the cornerstone of the market-failure approach to procompetitive-justification analysis. Where a restraint of trade alleviates a market failure, it is "efficient" (in the unique, consumer-focused sense in which modern antitrust courts use that term) and therefore potentially justified.

How are courts and enforcers to identify market failures? Modern antitrust law draws from partial-equilibrium price theory,${ }^{73}$ transaction-cost economics, ${ }^{74}$ game theory, ${ }^{75}$ and even behavioral economics ${ }^{76}$ It offers, in other words, something for everyone to criticize. The use of price theory's idealized 77 "perfect competition" model is no exception, having drawn rather intense criticism for its lack of descriptive accuracy, as well as its blindness to certain types of market failure and the procompetitive potential of nonstandard contracts. ${ }^{78}$ That said, the perfectcompetition model offers value in the present context: it can help to identify some common sources of market failure and to explain a great deal of the relevant case law. ${ }^{79}$

to engage in second-best alternatives and because consumers are required to shoulder the increased expense." Id. The Court, in other words, used the ideas of "efficiency" and "consumer welfare" interchangeably, suggesting that consumer welfare is the proper metric by which to assess the efficiency (or inefficiency) of a given instance of challenged conduct.

71. See, e.g., Jenefer Curtis, Efficiency Takes a Beating, GloBE \& MAIL (Dec. 15, 2001), https://www.theglobeandmail.com/arts/efficiency-takes-a-beating/article764764 [https:// perma.cc/CWK5-EFWV] (last updated Apr. 13, 2018) (reviewing JANICE GROss StEIN, THE Cult of EFFICIENCY (2002)).

72. See, e.g., Leegin, 551 U.S. at 902.

73. See, e.g., Meese, supra note 57, at 120 (describing the incorporation of price-theoretic models into antitrust law and economics).

74. See, e.g., Oliver E. Williamson, The Economics of Antitrust: Transaction Cost Considerations, 122 U. PA. L. REv. 1439 (1974)

75. E.g., Petruzzi's IGA Supermarkets, Inc. v. Darling-Del. Co., 998 F.2d 1224, 1233 (3d Cir. 1993) ("Game theory teaches us that a cartel cannot survive absent some enforcement mechanism because otherwise the incentives to cheat are too great.").

76. See Elizabeth M. Bailey, Behavioral Economics and U.S. Antitrust Policy, 47 Rev. IND. ORG. 355 (2015) (collecting and describing instances of U.S. antitrust courts relaxing the assumption of perfect rationality).

77. Or, as Meese wryly puts it, "antiseptic." Meese, supra note 57, at 120.

78. Alan J. Meese, Market Failure and Non-Standard Contracting: How the Ghost of Perfect Competition Still Haunts Antitrust, 1 J. COMPETITION L. \& ECON. 21, 22 (2005).

79. Cf. Robert H. Bork, The Antitrust Paradox: A Policy at War with Itself 60 (1993) ("[A]ntitrust must use the model [of perfect competition] and its implications as a guide to reasoning about actual markets ...."). 
Perfect competition is a partial-equilibrium model. ${ }^{80}$ How closely a given market approximates a state of perfect competition depends on several conditions. ${ }^{81}$ Deviations from at least some of these conditions tend to decrease the relevant market's efficiency. Most relevant for present purposes are the conditions of perfect information, ${ }^{82}$ lack of market power, ${ }^{83}$ zero transaction costs, ${ }^{84}$ lack of externalities, ${ }^{85}$ and rational behavior by market participants. ${ }^{86}$ Markets can also fail where individually welfare-maximizing actions, when taken by a group of individuals, have the paradoxical effect of leaving everyone worse off. ${ }^{87}$

To illustrate how a deviation from the idealized state of perfect competition can cause a market to perform less efficiently, consider the presence of high transaction costs. Such costs can make a given exchange unprofitable for sellers and/or buyers. ${ }^{88}$ Surplus-maximizing actors will not enter into such an exchange, even where it would, absent transaction costs, make both parties better off. ${ }^{89}$ The presence of high transaction costs has caused a market failure: the market will perform less efficiently than it would absent such costs. ${ }^{90}$ Certain restraints of trade can reduce transaction costs, facilitating mutually beneficial exchanges and increasing efficiency. ${ }^{91}$ The market-failure approach recognizes such restraints as (at least potentially) justified. ${ }^{92}$

80. See Hammer, supra note 24 , at $855-56$.

81. See generally Frank H. Knight, Risk, Undeertantty, and Profit 51-93 (1921) (listing requisite conditions for perfect competition).

82. Meese, supra note 57 , at 116.

83. See KNIGHT, supra note 81.

84. Id. at $116-17$.

85. See Herbert Hovenkamp, Antitrust Policy After Chicago, 84 MicH. L. REv. 213,244 (1985)

86. E.g., John M. Newman, The Myth of Free, 86 GEO. WASH. L. REv. 513 (2018).

87. See Maurice E. Stucke, Is Competition Always Good?, 1 J. ANTITRUst ENForCEMENT $162,179(2013)$.

88. For an accessible definition of "transaction costs," see David M. Driesen \& Shubha Ghosh, The Functions of Transaction Costs: Rethinking Transaction Cost Minimization in a World of Friction, 47 ARIz. L. REV. 61, 62 (2005) ("One can best understand transaction costs by contrasting them with production and purchase costs. Thus, for example, when a widget maker enters into a contract to supply a customer with widgets, neither the production costs incurred in manufacturing the widgets nor the money the customer pays to purchase the widgets, constitute transaction costs. But the money both sides expend in negotiating and enforcing the supply contract constitutes a transaction cost.").

89. Meese usefully distinguishes between "technological" transaction costs, defined as "bargaining and information costs that generally precede a transaction," and "nontechnological transaction costs," which "postdate relationship-specific investments that enhance product differentiation." Alan J. Meese, Reframing Antitrust in Light of Scientific Revolution: Accounting for Transaction Costs in Rule of Reason Analysis, 62 Hastings L.J. 457,459 (2010). This Article recognizes both types as cognizable causes of structural market failures.

90. See generally 2 Kenneth J. Arrow, General Equilibrium 134 (1983) (describing "transaction costs, which in general impede and in particular cases completely block the formation of markets").

91. See, e.g., Oliver E. Williamson, Economies as an Antitrust Defense Revisited, $125 \mathrm{U}$. PA. L. REV. 699, 723-26 (1977) (merger context).

92. See, e.g., Broad. Music, Inc. v. CBS, Inc., 441 U.S. 1 (1979). 
It bears emphasizing that not all of the conditions requisite for the economic model of perfect competition will necessarily promote efficiency in a given realworld market. For example, the model assumes rising average total costs. ${ }^{93}$ Such markets are best served by many small sellers. But in a market where average cost declines throughout some relevant range of output, production is subject to economies of scale. ${ }^{94}$ In markets with scale economies, the presence of many sellers - each with a higher-than-necessary cost structure - is likely inefficient..$^{95} \mathrm{~A}$ restraint of trade that "alleviates" market concentration caused by economies of scale does not necessarily increase, and may very well decrease, efficiency. As a result, the market-failure approach would not recognize such restraints as justified.

In sum, the market-failure approach to procompetitive-justification analysis recognizes that restraints of trade can sometimes improve the functioning of markets. Where a restraint alleviates a market failure, thereby increasing that market's efficiency, it is potentially justified. As this Article will demonstrate, this approach fits comfortably within the consensus framework for rule-of-reason analysis and antitrust law at large. ${ }^{96}$ It also produces more accurate decisions, with lower attendant error costs, than either of the two alternatives discussed below.

\section{B. Competitive Process}

The competitive-process approach purports to distinguish between pro- and anticompetitive restraints via their effects not on welfare or efficiency, but on "competition itself" or on the "competitive process." In other words, if a challenged restraint somehow benefits the competitive process, the defendant may avoid antitrust liability. Multiple antitrust scholars argue that "competitive process" is the

93. See, e.g., Eugene V. Rostow, The New Sherman Act: A Positive Instrument of Progress, 14 U. CHI. L. REV. 567, 575-76 (1947).

94. Horton provocatively suggests that such economies may be offset by a different kind of "efficiency," the antifragility of a collection of small units as compared to a single large unit. Horton, supra note 59, at 185.

95. See, e.g., Alan J. Meese, Debunking the Purchaser Welfare Account of Section 2 of the Sherman Act: How Harvard Brought Us a Total Welfare Standard and Why We Should Keep It, 85 N.Y.U. L. REv. 659, 693 (2010) ("Adherents to 'workable competition' . . . recognize[ed] that certain departures from perfect competition could actually generate more benefits than harms, despite resulting market power. The classic example was economies of scale ....").

96. See infra Part II. 
prevailing and appropriate approach.$^{97}$ Others, while conceding that it has fallen out of favor, nonetheless call for its resurrection. ${ }^{98}$

But the actual content of the competitive-process approach remains mercurial, a cipher. The scholarly arguments in favor of it never seem to identify what, exactly, constitutes the "competitive process." More than a half-century has passed since the Court first clearly invoked the competitive process approach to condemn a restraint of trade, yet terms like "competition" and "competitive process" are still "wonderfully ill-defined." 99

Whatever the competitive process may be, it apparently can be harmed. A plaintiff carries its initial burden by showing such harm. ${ }^{100}$ If (or, perhaps more accurately, when) the plaintiff succeeds, the burden then shifts to the defendant to demonstrate some offsetting benefit. ${ }^{101}$ If it is unclear what constitutes harm to the competitive process, it is even less clear what might qualify as a benefit. But, at least in theory, a defendant who succeeds in proving such a benefit may escape liability. ${ }^{102}$

A permissible reading of the relevant precedent suggests that the overriding concern does not lie with marketplace effects, placing this approach at loggerheads with the rest of modern antitrust law. ${ }^{103}$ Instead, the competitive-process approach derives from a group of rather vaguely defined rights. These include, but are not limited to, the right of a "single merchant" to compel a "group of powerful businessmen" to supply him with "the goods he needs to compete effectively,"

97. E.g., Werden, supra note 9; see also Barak Orbach, How Antitrust Lost Its Goal, 81 FORDHAM L. REV. 2253, 2256 (2013). Here and elsewhere, Orbach offers a convincing argument to the effect that the "consumer welfare" standard does not offer as much clarity as its proponents generally assume. While that may be so, it does not follow that the "competitive process" (or "competition") standard fares any better. In fact, the latter standard appears to offer even less clarity - unless it means simply that defendants always lose, in which case it offers a great deal of clarity but also (likely) an overly high likelihood of false positives. Orbach's historical account concludes that "competition" was the sole standard for the roughly seven decades between the passage of the Sherman Act and the release of Bork's The Antitrust Paradox. Orbach, supra, at 2277. This account does not, however, discuss Chicago Board of Trade.

98. See, e.g., Maurice E. Stucke \& Ariel Ezrachi, The Rise, Fall, and Rebirth of the U.S. Antitrust Movement, HARV. Bus. REv., Dec. 2017.

99. Hammer, supra note 24 , at 850 n.3.

100. If the Supreme Court ever applied (or blessed the application of) the full-scale rule of reason during the Competitive Process Era, this author is not aware of it. That said, one can infer that the plaintiff bore such an initial burden from the Court's per se jurisprudence. See, e.g., N. Pac. Ry. Co. v. United States, 356 U.S. 1, 8 (1958) ("[T] he essential prerequisites for treating the defendant's tying arrangements as unreasonable 'per se' were conclusively established below ...."). Despite the Court's usage of the passive voice in the quoted passage, it seems clear that the only actor who could have done the "establish[ing] below" was the plaintiff. $I d$.

101. Cf. id. (" [T] he defendant has offered to prove nothing there or here which would alter this conclusion.").

102. See id.

103. See, e.g., Daniel A. Crane, "The Magna Carta of Free Enterprise" Really?, 99 IowA L. REv. Bull. 17, 23 (2013) ("Antitrust is . . . best understood as a consequentialist body of law designed to maximize economic efficiency and consumer welfare.").

104. Klor's, Inc. v. Broadway-Hale Stores, Inc., 359 U.S. 207 (1959) (applying the per se 
"right" of traders to be "free" from various nonstandard contractual provisions, ${ }^{105}$ and a more general right of "freedom of action." 106

Given the lack of clarity in the area, one is left free (or, less charitably, forced) to speculate as to the source and content of these rights. Perhaps they derive from Lochnerian freedom of contract. Certain early U.S. Supreme Court antitrust decisions-which happen to lie squarely in the heart of the Lochner Era-do speak of antitrust-related "rights." Thus, for example, the Court in 1914 identified a single retailer's "unquestioned right to stop dealing with a wholesaler for reasons sufficient to himself." ${ }^{107}$ But by 1945, after the end of the Lochner Era, ${ }^{108}$ the Court was retreating from that hardline stance, referring to it as "true" only "in a very general sense." 109

Whatever their source, the rights that seem to underlie the competitive-process approach had the practical effect of rendering a great many agreements invalid under the antitrust laws. Application of the competitive-process approach rarely, if ever, identifies any procompetitive justifications. During the 1960s and early 1970s, when this approach was en vogue, nearly every restraint was treated as harmful to the

illegality rule to a thinly alleged "conspiracy" among multinational electronics manufacturers to refuse to deal with an independent retailer).

105. These include exclusive-territory restrictions, e.g., United States v. Topco Assocs., Inc., 405 U.S. 596, 611 (1972) ("[T] he Sherman Act gives to each Topco member and to each prospective member the right to ascertain for itself whether or not competition with other supermarket chains is more desirable than competition in the sale of Topco brand products."); group boycotts, e.g., Fashion Originators Guild of Am., Inc. v. FTC, 312 U.S. 457, 465 (1941) ("A]mong the many respects in which the Guild's plan runs contrary to the policy of the Sherman Act are these: it narrows the outlets to which garment and textile manufacturers can sell and the sources from which retailers can buy ... [and] subjects all retailers and manufacturers who decline to comply with the Guild's program to an organized boycott ... $. ")$; etc.

106. Fashion Originators, 312 U.S. at 465 ('[T] he Guild's plan . . takes away the freedom of action of members by requiring each to reveal to the Guild the intimate details of their individual affairs ....").

107. E. States Retail Lumber Dealers' Ass'n v. United States, 234 U.S. 600, 614 (1914).

108. See W. Coast Hotel Co. v. Parrish, 300 U.S. 379 (1937) (overturning Adkins v. Children's Hosp., 261 U.S. 525 (1923)).

109. Assoc. Press v. United States, 326 U.S. 1, 15 (1945). At least arguably, the Court subsequently lurched back toward this attitude. See, e.g., Monsanto Co. v. Spray-Rite Serv. Corp., 465 U.S. 752, 761 (1984) ("A manufacturer of course generally has a right to deal, or refuse to deal, with whomever it likes, as long as it does so independently."); see also Verizon Commc'ns, Inc. v. Law Offices of Curtis V. Trinko, LLP, 540 U.S. 398, 408 (2004) ("[A]s a general matter, the Sherman Act does not restrict the long recognized right of [a] trader or manufacturer engaged in an entirely private business, freely to exercise his own independent discretion as to parties with whom he will deal." (quoting United States v. Colgate \& Co., 250 U.S. 300, 307 (1919) (internal quotation marks omitted) (alteration in original))). But even these cases refer only to a "general" right, rather than the "unquestioned" right identified in Eastem States, 234 U.S. at 614. 
"competitive process," usually under the strict rule of per se illegality. ${ }^{110}$ Not much more than simple, one-off contracts escaped liability. ${ }^{111}$

\section{Type of Effect}

Some courts and enforcers instead attempt justification analysis using a typology of pre-approved marketplace effects. The inquiry comprises two steps. First, the analyst must assemble a checklist of effects that constitute valid procompetitive justifications. The typical list approves of restraints that "reduce cost, increase output or improve product quality, service, or innovation." 112 Second, the analyst simply ascertains whether the challenged restraint causes any of the effects on that list. ${ }^{113}$

Under the type-of-effect approach, a restraint that increases output, lowers price, etc., is justified ("reasonable") regardless of the reason it causes that effect. A restraint that decreases output, increases price, etc., is unjustified ("unreasonable"), again regardless of why it does so.

To illustrate, consider Law v. NCAA, in which the Tenth Circuit employed this approach to analyze a horizontal agreement capping coaches' salaries. ${ }^{114}$ After noting the cap's obvious anticompetitive effects, the court identified a checklist of valid procompetitive effects: "increasing output, creating operating efficiencies, making a new product available, enhancing product or service quality, and widening consumer choice." 115 The court also identified "mere profitability or cost savings" as effects that cannot justify restraints. ${ }^{116}$ Since the NCAA's proffered justification ("cost containment") was not on the "valid" list, and was in fact on the "invalid" list, the court rejected it. ${ }^{117}$

An extreme version of the type-of-effect approach focuses exclusively on output effects. This simplistic approach seeks to cabin all of antitrust analysis to a mere output inquiry. If a challenged restraint decreases output, it is always unreasonable. If it increases output, it is always reasonable. ${ }^{118}$ Leading scholars and jurists, particularly Robert Bork, advocate adoption of this output-only variant. ${ }^{119}$

110. See, e.g., Werden, supra note 9, at 729 ("Northerm Pacific began an era during which the Supreme Court saw a 'pernicious effect' in every restraint it examined.").

111. See id.

112. McWane, Inc. v. FTC, 783 F.3d 814, 841 (11th Cir. 2015) (quoting approvingly the FTC's decision in McWane, Inc., 2014-1 Trade Cas. (CCH) $978,670,2014$ WL 556261 (FTC Jan. 30, 2014) (internal quotation marks omitted)).

113. This categorical approach has been described, during personal conversations, by a number of antitrust practitioners and scholars as a "lawyerly" approach-it appeals to the lawyerly instinct toward simplifying typologies.

114. 134 F.3d 1010 (10th Cir. 1998).

115. Id. at 1023 .

116. Id. ("[M]ere profitability or cost savings have not qualified as a defense under the antitrust laws.").

117. Id.

118. See, e.g., Herbert Hovenkamp, Mark D. Janis, Mark A. Lemley, Christopher R. Leslie \& Michael A. Carrier, IP and Antitrust: An Analysis of Antitrust Principles ApPLIED TO INTELlectuAL PROPERTy LAW $§ 7.03$ [A] (3d ed. 2017) ("Fundamentally, the rule of reason considers whether a restraint is output increasing or output decreasing.").

119. Transcript of Oral Argument at 5, Ohio v. Am. Express Co., 138 S. Ct. 2274 (2018) 
Sophisticated proponents of this approach generally appear to agree that maximizing some form of welfare-not maximizing output per se-is the overarching goal of antitrust. ${ }^{120}$ Thus, the output-only variant can be understood as heuristic in nature. If conduct that increases output virtually always increase consumer welfare, then output effects could perhaps be used as a shortcut to simplify the judicial task.

Unfortunately, this is not the case. Bork's attempt to craft a shortcut would (somewhat ironically) create an antitrust paradox: a legal regime that harms that which it ostensibly protects. Actual output effects are often difficult, if not impossible, to assess in a given case, even where harm to consumer welfare has clearly occurred. Yet the output-only approach would overlook-and therefore implicitly bless-such harm. Moreover, conduct that increases output does not always increase - and may, in fact, decrease - consumer welfare. ${ }^{121}$ Here again, an output-only approach would overlook harm to welfare. Finally, antitrust courts are often confronted with claims that focus on other aspects of competition: a given case may hinge on quality, innovation, etc. ${ }^{122}$ The output-only shortcut offers no guidance in such cases. ${ }^{123}$ Thus, the discussion that follows will focus on the type-of-effect approach as it is actually employed, rather than the more extreme output-only variant.

\section{DOCTRINAL BASIS FOR THE MARKET-FAILURE APPROACH}

Antitrust doctrine generally supports the view that a restraint is procompetitive if - but only if - it alleviates a market failure. On its face, Sherman Act $\$ 1$ condemns "[e]very ... restraint of trade." 124 That phrase invoked a well-established common law doctrine disfavoring contractual noncompete provisions. ${ }^{125}$ Initially, all such provisions were held to be against public policy and therefore invalid. ${ }^{126}$ But, recognizing the opportunity to facilitate welfare-enhancing investments and transactions, courts relaxed the doctrine to prohibit only "unreasonable" noncompete agreements. Under this standard, such agreements were "reasonable" (and

(No. 16-1454) (question by Justice Gorsuch); BoRK, supra note 79, at 122 (1993) ("The task of antitrust is to identify and prohibit those forms of behavior whose net effect is output restricting and hence detrimental.").

120. See, e.g., Bork, supra note 79 (arguing for a total welfare standard, which Bork referred to as "consumer welfare").

121. See, e.g., Mark R. Patterson, Coercion, Deception, and Other Demand-Increasing Practices in Antitrust Law, 66 AnTITRUST L.J. 1, 5-6 (1997) ("[C]oercion and deception can also increase demand and output, yet may injure consumers."); infra note 165 and accompanying text (noting that externalizing costs tends to inefficiently increase output).

122. E.g., Allensworth, supra note 4.

123. Unless, that is, "output" is a synecdoche for these other aspects of competition, in which case the output-only variant adds nothing of value relative to the broader type-of-effect approach.

124. 15 U.S.C. $\& 1$ (2012).

125. Cf. United States v. Trans-Missouri Freight Ass'n, 166 U.S. 290, 328 (1897) (construing the Sherman Act's prohibition of "restraints of trade," recognizing that "[c]ontracts in restraint of trade have been known and spoken of for hundreds of years, both in England and in this country").

126. See, e.g., Standard Oil Co. of N.J. v. United States, 221 U.S. 1, 51 (1911). 
enforceable) so long as they were no broader than necessary to "protect the legitimate commercial interests of the party seeking protection." 27 This consequentialist mode of analysis provided a groundwork upon which nascent antitrust laws would build.

After some early uncertainty, ${ }^{128}$ the U.S. Supreme Court quickly concluded that Sherman Act $\S 1$, like its common law antecedent, condemns only unreasonable restraints of trade. ${ }^{129}$ Since all contracts "restrain trade" to some degree, a literal reading of the statute would have been untenable. ${ }^{130}$ In its seminal Standard Oil opinion in 1911, the Court pronounced that "the standard of reason which had been applied at the common law ... was intended to be the measure used" in applying the Sherman Act. ${ }^{131}$ Thus, antitrust courts' primary task under Sherman Act $\S 1$ became deciding which agreements "in restraint of trade" are unjustified and unreasonable, and which are justified and reasonable.

\section{A. Early Support}

Seven years after Standard Oil, Justice Brandeis's Chicago Board of Trade (CBOT) opinion set forth the classic formulation of the rule of reason: "The history of the restraint, the evil believed to exist, the reason for adopting the particular remedy, the purpose or end sought to be attained, all are relevant facts." ${ }^{132}$ Though sometimes criticized as overbroad, ${ }^{133}$ Brandeis's articulation highlights a useful point: left unrestrained in a literal sense, markets may fail to produce optimal results, i.e., cause "evil." What looks like a harmful restraint of trade may, in fact, be a "remedy" for undesirable results. ${ }^{134}$

Though Brandeis wrote at a time before the modern economic concept of market failure had crystallized, ${ }^{135}$ his $C B O T$ opinion invoked its underlying tenets. The challenged conduct - a rule freezing the price of grain during after-hours trading was unquestionably a "restraint" of trade, specifically price competition. Yet the $C B O T$ Court was hospitable to a number of the defendant's procompetitive justifications because, as Brandeis put it, the restraint "helped to improve market

127. See David Cabrelli \& Louise Floyd, New Light Through Old Windows: Restraint of Trade in English, Scottish, and Australian Employment Laws(-) Emerging and Enduring Issues, 26 INT'L J. COMP. LAB. L. \& INDUS. ReL. 167, 168 (2010).

128. Trans-Missouri, 166 U.S. at 327 (rejecting argument that Sherman Act $\S 1$ "does not mean what the language used therein plainly imports, but that it only means to declare illegal any such contract which is in unreasonable restraint of trade" (emphasis added)).

129. See United States v. Joint Traffic Ass'n, 171 U.S. 505 (1898).

130. Id. at 568 ("To suppose ... that the effect of the decision in the Trans-Missouri case is to render illegal most business contracts . . . , however indispensable and necessary they may be . . is to make a most violent assumption, and one not called for or justified by the decision mentioned, or by any other decision of this court.").

131. 221 U.S. at 60.

132. Bd. of Trade of Chi. v. United States, 246 U.S. 231, 238 (1918).

133. See, e.g., Edward D. Cavanagh, The Rule of Reason Re-Examined, 67 Bus. LAw. 435, 435 (2012) ("From the beginning, federal courts have been troubled by the open-ended nature of the Brandeis formulation of the Rule of Reason . . ..").

134. See Werden, supra note 9, at 728 ("Brandeis invited only the justification that a restraint makes the market work better.").

135. See Hovenkamp, supra note $65, \S 2.1$, at 71 . 
conditions." ${ }^{136}$ Importantly, Brandeis was hospitable to the proffered justifications not because of any supposed effects on price or output. Rather, his opinion contemplated (if a bit clumsily) the virtues of correcting market failures by, e.g., correcting information asymmetries. ${ }^{137}$

\section{B. The Competitive Process Era}

Beginning approximately with Northern Pacific in $1958,{ }^{138}$ the Court entered its "Competitive Process Era," 139 a period characterized by plaintiff-friendly rulemaking. ${ }^{140}$ During this era, the Court condemned outright many restraints that have subsequently been treated with less suspicion. Few, if any, virtues could insulate a restraint from antitrust liability. ${ }^{141}$ The Northern Pacific Court, for example, unanimously condemned tying arrangements as per se illegal. ${ }^{142} \mathrm{Albrecht}$, decided in 1968, imposed a similar per se ban on vertical maximum-resale-price agreements. ${ }^{143}$ In 1972, the Topco majority applied the per se rule to market-division agreements, ${ }^{144}$ despite evidence suggesting that the challenged agreement was not harmful. ${ }^{145}$

136. Bd. of Trade of Chi., 246 U.S. at 240 (emphasis added).

137. Id. ("Before [the restraint's] adoption, bids were made privately. Men had to buy and sell without adequate knowledge of actual market conditions. This was disadvantageous to all concerned, but particularly so to country dealers and farmers.").

138. N. Pac. Ry. Co. v. United States, 356 U.S. 1 (1958).

139. Some scholars instead refer to this as the Court's "inhospitality era." Meese, supra note 57 , at 146 .

140. See generally HovenKamp, supra note $65, \S 2.1$, at 82 (“'1960's antitrust policy ... was openly hostile toward innovation and large scale development, and a zealous protector of the right of small business to operate independently.").

141. Though this Article focuses on restraints of trade, merger case law during this time exhibited analogous hostility to "efficiencies" defenses. See, e.g., FTC v. Procter \& Gamble Co., 386 U.S. 568, 580 (1967) ("Congress was aware that some mergers which lessen competition may also result in economies but it struck the balance in favor of protecting competition."). Subsequent courts have hewed closer to this precedent than to analogous restraints-of-trade precedent. See, e.g., United States v. Aetna, Inc., 240 F. Supp. 3d 1, 96 (D.D.C. 2017) (requiring "proof of extraordinary efficiencies" to justify a presumptively anticompetitive merger).

142. 356 U.S. at 8.

143. Albrecht v. Herald Co., 390 U.S. 145, 152 (1968).

144. United States v. Topco Assocs., Inc., 405 U.S. 596 (1972).

145. See Alan J. Meese, Competition and Market Failure in the Antitrust Jurisprudence of Justice Stevens, 74 FordHAM L. Rev. 1775, 1782 n.56 (2006). For a contrary view, see Peter C. Carstensen \& Harry First, Rambling Through Economic Theory: Topco's Closer Look, in Antitrust StoriEs 174-76 (Eleanor M. Fox \& Daniel A. Crane eds., 2007). Carstensen and First suggest, rather persuasively, that at least some members of the Court were concerned about the possibility that Topco members could have used Topco as a vehicle to launch multiple private-label brands, thus eliminating the possibility that a given member would be able to free-ride off a nearby rival member's promotional efforts. Thus, for example, a Giant grocery store could carry and promote its own Giant private-label goods, while a nearby 7Eleven store could carry and promote its own 7-Eleven-branded private label. Giant's promotional efforts would presumably be designed to increase consumer awareness of its own 
These decisions were primarily concerned with protecting "competition" or the "competitive process," rather than consumer welfare. ${ }^{146}$ The Northern Pacific Court was troubled by tying arrangements' "pernicious effect on competition." 147 The Albrecht Court condemned vertical maximum-resale-price agreements as per se illegal out of concern that such "schemes" disrupt "the forces of the competitive market." 148 The Topco majority flatly rejected the defendant's proffered justifications, reasoning that antitrust tribunals are unable "to weigh, in any meaningful sense, destruction of competition in one sector of the economy against promotion of competition in another sector." 149

But these decisions never defined, exactly, what constitutes "competition" or the "competitive process." 150 Instead, these opinions explained themselves by reference to an ill-defined bundle of "rights" and "freedoms." The Northern Pacific Court, for example, fretted over the loss of landowners' "freedom to deal with competing carriers." 151 The Albrecht majority was concerned that vertical maximum resale price agreements "cripple the freedom of traders." 152 The Topco majority stated that the antitrust laws protect "our fundamental personal freedoms," 153 and that "guaranteed each and every business, no matter how small, is the freedom to compete - to assert with vigor, imagination, devotion, and ingenuity whatever economic muscle it can muster." 154 Beautiful though Justice Marshall's prose may be, what guidance does it

private label, eliminating the possibility that 7-Eleven could take a free ride. See id. Even assuming this was a realistic possibility, however, it is difficult to see how the restraints could have meaningfully harmed the relevant markets, given the paltry market shares held by Topco's members.

146. See Werden, supra note 9 , at 757.

147. 356 U.S. at 5. That said, the Court also foreshadowed the Modern Era by emphasizing the centrality of efficiency to antitrust law: "[The Sherman Act] rests on the premise that the unrestrained interaction of competitive forces will yield the best allocation of our economic resources...." Id. at 4 .

148. Albrecht, 390 U.S. at 152.

149. Topco Assocs., 405 U.S. at 609-10.

150. Indeed, as Orbach (a proponent of the "competition/competitive-process" standard) observes, "[i]n 1890, Congress passed a competition law without meaningfully talking about competition." Orbach, supra note 97 , at 2268 . That said, Orbach points out that a great number of these decisions did, in fact, invoke "competition" as the relevant touchstone for analysis, an observation that aligns with the present claims. See id. at 2270 n.96 (citing City of Lafayette v. La. Power \& Light Co., 435 U.S. 389, 398 (1978) ("[By enacting the Sherman Act,] Congress ... sought to establish a regime of competition as the fundamental principle governing commerce in this country."); see also Topco Assocs., 405 U.S. at 610 ("Antitrust laws in general, and the Sherman Act in particular, are the Magna Carta of free enterprise. They are as important to the preservation of economic freedom and our free-enterprise system as the Bill of Rights is to the protection of our fundamental personal freedoms."); White Motor Co. v. United States, 372 U.S. 253, 263 (1963); Brown Shoe Co. v. United States, 370 U.S. 294, 330 (1962) ("CA]ntitrust laws . . . are intended primarily to preserve and stimulate competition."); N. Pac. Ry. Co. v. United States, 356 U.S. 1, 4 (1958)).

151. 356 U.S. at 8.

152. Albrecht, 390 U.S. at 152.

153. 405 U.S. at 610.

154. Id. 
offer? To a given lower court attempting to assess a particular justification, what does it mean?

In practice, using the "competitive process" as the sine qua non of antitrust liability meant that the existence of almost any nonstandard contractual arrangement could satisfy a plaintiff's initial burden. The Court's vision of "competition" seems to have involved large numbers of small sellers and buyers transacting via simple spot contracts. Any agreement deviating from that ideal therefore represented a threat to the competitive process. All a plaintiff needed to do to satisfy its initial burden was to demonstrate the existence of the challenged restraint. As a result, this era was relatively plaintiff-friendly.

But viewing these decisions through the lens of procompetitive-justification analysis reveals an additional insight: the Competitive-Process Era was also distinctly defendant-unfriendly. Using the competitive process as the touchstone for antitrust liability not only lowers the bar for plaintiffs attempting to show competitive harm, but also forecloses the primary-perhaps the only-avenue available to defendants attempting to offer justifications. Consider the Topco majority's opinion, which observed that "[i]mplicit in such freedom is the notion that [competition] cannot be foreclosed with respect to one sector of the economy because certain private citizens or groups believe that such foreclosure might promote greater competition in a more important sector of the economy." 155

In other words, defendants could not argue that unrestrained competition was producing suboptimal results. That raises a question: If defendants could not make that argument, could they ever justify their conduct? The apparent answer-reflected in the multiplicity of per se illegality rules established or reaffirmed during this period-was that they could not.

These decisions were subsequently relegated (for the most part ${ }^{156}$ ) to the dustbin of history. The Court explicitly overruled many of them, ${ }^{157}$ and has substantially eroded others. ${ }^{158}$ The Competitive-Process Era met its end less than twenty years after Northern Pacific marked its birth.

155. Id. (emphasis added).

156. Topco has not been explicitly overruled, though some lower courts have blatantly disregarded it. See, e.g., Polk Bros., Inc. v. Forest City Enters., Inc., 776 F.2d 185 (7th Cir. 1985); E. Thomas Sullivan \& Jefrrey L. Harrison, Unders tanding Antitrust and Its ECONOMIC IMPLICATIONS $\S 4.14$, at 160 (5th ed. 2008) ("The question arises whether [such cases] are reconcilable with Topco or whether they are mere examples of judicial activism by lower federal court judges.").

157. See, e.g., Continental T.V., Inc. v. GTE Sylvania, Inc., 433 U.S. 36, 58 (1977) (overruling the per se rule for vertical exclusive-territory restrictions announced in United States v. Arnold, Schwinn \& Co., 388 U.S. 365 (1967)).

158. Compare, e.g., Jefferson Parish Hosp. Dist. No. 2 v. Hyde, 466 U.S. 2 (1984) (requiring a finding of market power before condemning tying arrangements), with N. Pac. Ry. Co. v. United States, 356 U.S. 1 (1958) (rejecting a requirement of "monopoly power" and requiring only "sufficient economic power"). 


\section{The Modern Era}

By 1977, the economic conceptions of efficiency and market failure had gained considerable clarity. In GTE Sylvania, often heralded as marking the beginning of the "Modern Era" of antitrust, ${ }^{159}$ the Court reversed its earlier per se prohibition of vertical exclusive-territory restraints. At a high level, the rationale for treating such restraints with less suspicion was their likelihood of creating "efficiencies." 160 More specifically, the majority reasoned such restraints can alleviate "market imperfections such as the so-called 'free rider' effect." 161 Thus, the Court ushered in the Modern Era of antitrust by explicitly invoking the market-failure approach to justification analysis. Free-riding-which can cause welfare-reducing underproduction-results from the presence of externalities, a common cause of market failure. ${ }^{162}$ Note also that the Court's focus was not limited to whether the restraint created a particular type of marketplace effect, such as higher output or lower prices. ${ }^{163}$ Rather, the Court held that certain restraints may be justified where they alleviate market failures.

One year later, the Court issued a rather puzzling opinion best understood as a leftover from the Competitive Process Era. Professional Engineers involved a tradeassociation rule that prohibited members from submitting price bids to potential customers. ${ }^{164}$ The association attempted to justify its rule by arguing that without the rule, the market would produce suboptimally low-quality engineering services. ${ }^{165}$ This was a classic market-failure argument: a combination of information asymmetries and irrational (time-inconsistent) behavior by consumers caused the unrestrained market to fail to optimize welfare. ${ }^{166}$

In sweeping language, however, Justice Stevens condemned the proffered justification as "nothing less than a frontal assault on the basic policy of the Sherman Act." 167 Stevens castigated the association for arguing that competition itself was "bad." 168 That was, of course, precisely what the association was arguing: that the challenged restraint alleviated the relevant market's tendency to produce "bad" outcomes. The problem with this argument, according to Stevens, was that "the

159. See, e.g., Lindsey M. Edwards \& Joshua D. Wright, The Death of Antitrust Safe Harbors: Causes and Consequences, 23 GEO. MASON L. REv. 1205, 1205 (2016).

160. See GTE Sylvania, Inc., 433 U.S. at 54.

161. Id. at 55 (emphasis added).

162. See, e.g., Massimo Motta, Competition Policy: Theory and Practice 314-16 (2004)

163. It was the concurring opinion that appeared more focused on the restraint's "outputenhancing possibilities," rather than its efficiency-enhancing possibilities. GTE Sylvania, 433 U.S. at 70 (White, J., concurring in the judgment).

164. Nat'1 Soc'y of Prof'1 Engineers v. United States, 435 U.S. 679, 684 (1978).

165. See, e.g., Brief for Petitioner, 435 U.S. 679 (1978), No. 76-1767, 1977 WL 205310 , at $* 54$ ("NSPE contends . . that . . the submission of a bid . . . before the problem can possibly be comprehended or an adequate approach to it proposed limits the amount and quality of analysis ultimately applied to the problem ....").

166. See John M. Newman, Rationalizing Procompetitive Justifications (unpublished manuscript) (on file with author).

167. Prof'l Engineers, 435 U.S. at 695.

168. Id. 
statutory policy precludes inquiry into the question whether competition is good or bad." 169 Professional Engineers thus appears to have employed the retrograde competitive-process approach, ${ }^{170}$ which leaves little to no room for defendants to proffer justifications. Stevens's analysis was straightforward: (1) the Sherman Act assumes that restraints on competition are bad, (2) the defendant restrained competition, so (3) the defendant violated the Sherman Act. The competitive-process approach effectively foreclosed the only possible means by which the defendant could have justified its conduct.

The following year (1979), the Court issued $B M I$ and with it signaled a clear return to the market-failure approach. At issue was a joint copyright-licensing agreement that involved horizontal price-fixing. ${ }^{171}$ Unrestrained, the relevant market exhibited prohibitive transaction costs due to "the impracticability of negotiating individual licenses for each composition." 172 The restraint eliminated such transaction costs, which are a textbook source of market failure. ${ }^{173}$ Eight justices - and the DOJ as amicus-agreed that even a horizontal price-fixing agreement should receive ruleof-reason treatment where it alleviates a market failure. ${ }^{174}$ Only Justice Stevens dissented. ${ }^{175}$

In 1984, the Supreme Court again employed the market-failure approach to justification analysis. NCAA v. Board of Regents involved an arrangement between undergraduate universities to jointly license the right to televise amateur athletic

169. Id. Despite its peculiar reasoning, the Professional Engineers majority likely reached the correct substantive outcome. There were likely alternative restraints available to the association that would have been much less restrictive, yet still offered similar benefits. And, as demonstrated below, Stevens's hostility was most likely a misdirected response to the particular type of market failure allegedly corrected by the restraint.

170. At the very least, Stevens invoked that approach. See Meese, supra note 57, at 10910 (arguing that the Professional Engineers Court actually applied a market-failure approach).

171. Broad. Music, Inc. v. CBS, Inc., 441 U.S. 1 (1979).

172. Id. at 15 (quoting Brief for United States as Amicus Curiae on Petition for Certiorari, K-91, Inc. v. Gershwin Publ'g Corp., 389 U.S. 1045 (1968) (internal quotation marks omitted)).

173. See supra notes $89-93$ and accompanying text.

174. Broad. Music, Inc., 441 U.S. at 15 ("[T]he United States disagrees with the Court of Appeals in this case and urges that the blanket licenses . . . are not per se violations of the Sherman Act."). Some subsequent authorities instead describe $B M I$ as hinging on the output increase caused by the restraint. See, e.g., SCFC ILC, Inc. v. Visa USA, Inc., 36 F.3d 958, 964 (10th Cir. 1994). Under this view, BMI exemplifies the type-of-effect approach. But the Court mentioned "output" only in passing, and not strictly in connection with procompetitive justifications. 441 U.S. at 20 (framing the zero-step of analysis as a question of whether "the practice facially appears to be one that would always or almost always tend to restrict competition and decrease output .... or instead one designed to increase economic

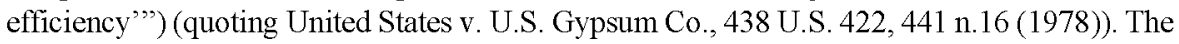
majority did, however, place great weight on the fact that "a bulk license of some type is ... necessary to achieve the[] efficiencies." Id. at 21. In other words, the reduction of transaction costs (which had previously caused a market failure) - not the resulting output increase per se-dictated Rule of Reason treatment.

175. BMI, 441 U.S. at 25. 
sporting events. ${ }^{176}$ Because such agreements can be "efficient," the majority opinion-written by none other than Justice Stevens-found per se treatment to be inappropriate, even where the challenged restraint was a rather blatant outputreduction scheme. ${ }^{177}$

The NCAA majority at times did use the terms "efficiency" and "increase[d] output" roughly interchangeably, ${ }^{178}$ arguably suggesting a type-of-effect approach. This is, however, not the best reading. Some early analysts, Bork in particular, often appeared to conflate efficiency and higher output, but the modern consensus is that higher output is not always an efficient outcome. ${ }^{179}$ A variety of inefficient conditions and strategies (externalized costs, coercion, overconsumption, deception, etc.) can increase output. ${ }^{180}$ Thus, the $N C A A$ Court's emphasis on output effects can most helpfully be understood not as endorsing Bork's extreme-form type-of-effect analysis, but as a response to the particular restraint at issue: an agreement to restrict output. A decision analyzing an output restriction will naturally focus on outputbut it would be a mistake to conclude that all of antitrust is therefore limited to a mechanical output analysis.

In 1997, State Oil Co. v. Khan overturned the decades-old per se rule against vertical restraints setting maximum retail prices. ${ }^{181}$ That rule traced its roots to Albrecht, ${ }^{182}$ an opinion the Khan Court characterized as "grounded in the fear that maximum price fixing by suppliers could interfere with dealer freedom." 183 Ironically, as the Khan Court pointed out, the ban on vertical maximum price fixing had prompted many suppliers to vertically integrate, thereby "eliminating the very independent trader for whom Albrecht professed solicitude." 184 Justice O'Connor, writing for a unanimous majority, identified the following procompetitive justification for vertical maximum price fixing: "A supplier might . . . fix a maximum resale price in order to prevent his dealers from exploiting a monopoly position." 185 Monopoly power (like transaction costs and externalities) is a textbook cause of market failure. ${ }^{186}$ By overruling Albrecht and disapproving of its normative basis, Khan emphatically rejected the competitive-process approach. And by focusing on the restraint's alleviation of a market failure, rather than its effect on output, Khan continued the Modern Era's embrace of the market-failure approach.

176. NCAA v. Bd. of Regents of Okla., 468 U.S. 85 (1984).

177. Id. at 103. The Court ultimately rejected the NCAA's proffered justifications ("efficiency justification[s]") as being factually and legally unsupported. See id. at 114-15.

178. Id. at 114 .

179. See, e.g., Patterson, supra note 121.

180. See infra notes 292-95 and accompanying text.

181. 522 U.S. 3 (1997).

182. Albrecht v. Herald Co., 390 U.S. 145 (1968).

183. 522 U.S. at 16.

184. Id. at 16-17 (quoting 8 Phillip AreEda, AnTitrust Law 1635, at 395 (1989)).

185. Id. at 16 (quoting Khan v. State Oil Co., 93 F.3d 1358, 1362 (7th Cir. 1996) (internal quotation marks omitted)).

186. Richard G. Lipsey \& Colin Harbury, First Principles of Microeconomics 169 (2d ed. 1992) ("[T]here is clearly a case to be made against monopoly on grounds of market failure ...."). 
The Supreme Court's most recent in-depth justification analysis appeared in its 2007 Leegin decision. ${ }^{187}$ The Leegin Court again employed the language of market failure and efficiency, this time to strike down a longstanding rule that vertical minimum resale price restraints were per se illegal. Because such restraints may often be the "most efficient way" 188 to lower certain transaction costs, ${ }^{189}$ decrease information asymmetries, ${ }^{190}$ and prevent free riding from "forcing [firms] to cut back [their] services to a level lower than consumers would otherwise prefer," rejected per se illegality in favor of the rule of reason. Each of these-transaction costs, information asymmetries, and free rider problems-is a textbook cause of market failure. More recently still, the 2018 Ohio v. American Express Co. decision mentioned alleviating "negative externalities"-another textbook source of market failure ${ }^{192}$-as a possible procompetitive justification. ${ }^{193}$

In sum, nearly a century of U.S. Supreme Court antitrust precedent counsels in favor of the market-failure approach to justification analysis. ${ }^{194}$ Against this

187. Leegin Creative Leather Prods., Inc. v. PSKS, Inc., 551 U.S. 877 (2007).

188. Id. at 892 .

189. Id. ("It may be difficult and inefficient for a manufacturer to make and enforce a contract with a retailer specifying the different services the retailer must perform.").

190. Id. at 891 (observing that resale-price maintenance may incentivize new entry by inducing firms to "make the kind of investment of capital and labor that is often required in the distribution of products unknown to the consumer" (internal quotation marks omitted) (emphasis added)).

191. Id.

192. See, e.g., Richard A. Posner \& Frank H. Easterbrook, Antitrust: CAses, Notes, AND OTHER Materials 176 (2d ed. 1981).

193. See Ohio v. Am. Express Co., 138 S. Ct. 2274, 2289 (2018) ("These agreements actually stem negative externalities in the credit-card market.").

194. The Court's Modern Era jurisprudence does frequently invoke the adage that antitrust laws are meant to protect "competition, not competitors." See Leegin, 551 U.S. at 906 (quoting Atlantic Richfield Co. v. USA Petroleum Co., 495 U.S. 328, 338 (1990)); Cargill, Inc. v. Monfort of Colorado, Inc., 479 U.S. 104, 115 (1986) (quoting Brown Shoe Co. v. United States, 370 U.S. 294, 320 (1962)); Brunswick Corp. v. Pueblo Bowl-O-Mat, Inc., 429 U.S. 477,488 (1977) (quoting Brown Shoe, 370 U.S. at 320). But it has generally done so in the context of "antitrust injury." The statement originated in Brown Shoe, a case that condemned a merger between horizontal rivals that possessed relatively small market shares. Brown Shoe, 370 U.S. at 319-21. But the particular discussion in Brown Shoe involved two hypothetical mergers that would not (per the majority) have violated Clayton Act $\S 7$ : "a merger between two small companies to enable the combination to compete more effectively with larger corporations dominating the relevant market" (presumably due to economies of scale) and "a merger between a corporation which is financially healthy and a failing one which no longer can be a vital competitive factor in the market." Id. at 319. The Court was, in Brunswick Corp., faced with the former. And in that case, citing Brown Shoe, the Court identified the "antitrust injury" doctrine. Under that doctrine, a plaintiff cannot make out an antitrust claim by alleging that it has (for example) lost customers to a more efficient rival. The Court's subsequent reiterations of this maxim have been in similar contexts and are properly understood as references to this discrete concept, rather than a full-throated endorsement of the competitiveprocess standard. Indeed, at least one of these subsequent invocations was expressly welfarerelated. See Leegin, 551 U.S. at 906 (referring to state fair-trade laws as "[d]ivorced from competition and consumer welfare" and "designed to save inefficient small retailers from their 
backdrop, the relatively brief Competitive Process Era appears to be a historical aberration. And had Professional Engineers been issued just a few years earlier, it would today most likely be viewed as simply another relic of that bygone age. It is only by historical accident that Professional Engineers falls within what has become viewed as the Modern Era of antitrust, an accident that has perhaps caused it to attract more than its share of scholarly attention. In fact, Professional Engineers was at least arguably overruled by multiple subsequent decisions, including the majority opinion in NCAA v. Board of Regents - which Stevens himself penned. ${ }^{195}$ In hindsight, it seems Justice Stevens was wrong to flatly condemn all justifications that hinge on unrestrained competition producing "bad" outcomes. The majority of modern precedent holds that alleviating a market failure is an acceptable procompetitive justification.

\section{Assessing Non-Welfare "Justifications"}

Antitrust defendants occasionally proffer non-welfare-related explanations for their conduct. As we have seen, however, the bulk of authority indicates that only alleviating a market failure - and thereby increasing welfare — can give rise to a valid justification. It follows that, at least as a purely doctrinal matter, non-welfare explanations should not be cognizable under the rule of reason, i.e., they should not come into play either at the zero-step of analysis or during a full-scale inquiry. Instead, such explanations are to be considered only at the very outset of judicial decision-making.

It is worth pausing to note that this Article employs the signifier "non-welfare" to refer to justifications unrelated to the economic conceptions of welfare and market failure. Elsewhere, such justifications are occasionally discussed under the appellation "noneconomic." 196 But "economic" as a modifier could apply to every possible justification-Merriam-Webster, for example, defines "economic" as "of, relating to, or based on the production, distribution, and consumption of goods and services." 197 Moreover, modern economics as a discipline encompasses an exceedingly broad variety of subject matters. ${ }^{198}$ Whether anything at all (or at least anything that could be the subject of an antitrust lawsuit) remains "non-economic" is rather doubtful. As the scope of the discipline continues to grow, the "economic/non-economic" dichotomy becomes increasingly unhelpful. ${ }^{199}$

inability to compete," in "contrast" with antitrust laws).

195. NCAA v. Bd. of Regents of Okla., 468 U.S. 85 (1984).

196. See, e.g., Julie L. Seitz, Comment, Consideration of Noneconomic Procompetitive Justifications in the MIT Antitrust Case, 44 EMORY L.J. 395 (1995); see also Robert Pitofsky, The Political Content of Antitrust, 127 U. PA. L. REV. 1051, 1051 (1979) ("The issue among most serious people has never been whether non-economic considerations should outweigh significant long-term economies of scale, but rather whether they had any role to play at all ....").

197. Economic, MERRLAM-WEBSTER, https://www.merriam-webster.com/dictionary /economic [https://perma.cc/AR6G-6W65].

198. See, e.g., Herbert A. Simon, Altruism and Economics, 83 Am. ECon. Rev. 156 (1993).

199. See, e.g., David W. Barnes, Nonefficiency Goals in the Antitrust Law of Mergers, 30 WM. \& MARY L. REv. 787, 797 (1989) (“[A] distinction is drawn between . . efficiency goals 
Consequently, the present discussion dispenses with "non-economic" in favor of the more descriptive "non-welfare."

The antitrust enterprise does immunize some truly non-welfare-motivated conduct from liability. But this immunity is bestowed by labeling such conduct "noncommercial" at the very outset of a given case. Noncommercial conduct falls outside the ambit of the Sherman Act, which by its terms applies only to "trade" or "commerce." 200 Thus, for example, the Eighth Circuit in Missouri v. NOW"201 declined to apply antitrust law to a boycott organized by the National Organization for Women (NOW). NOW refused to hold conventions in states that had not ratified the proposed Equal Rights Amendment to the U.S. Constitution. ${ }^{202}$ Recognizing the boycott's "social" and "political" purpose, the court deemed the challenged restraint to be outside the scope of the Sherman Act. ${ }^{203}$ This decision was reached before the zero-stage of analysis (deciding whether to apply the rule of reason or the per se rule), and certainly before proceeding to the justification step of full-scale rule of reason analysis. On somewhat analogous facts (a politically motivated boycott), the U.S. Supreme Court expressed similar sentiments. ${ }^{204}$

But lower courts have occasionally attempted to weigh non-welfare justifications as part of a full-scale rule of reason analysis. USA Equestrian provides a rather striking example. The case involved horse show competitions organized by a national governing body whose members owned the horses that competed in the shows. ${ }^{205}$

and ... nonefficiency goals. Although it is tempting to label these two categories 'economic' and 'noneconomic' goals, those labels are less useful . . . because there is substantial economic content even in the social and political goals."). In fact, the term was likely unhelpful from the beginning. Modern economics stakes out incredibly broad territory-the American Economic Association, for example, defines "economics" as "the study of scarcity, the study of how people use resources, or the study of decision-making." What Is Economics? Understanding the Discipline, AM. ECON. ASS'N, https://www.aeaweb.org/resources /students/what-is-economics [https://perma.cc/XTN9-EFRY]. With such an all-encompassing definition in place, one might well ask whether any aspect of human interaction could properly be considered "noneconomic." For an admirably broad early definition, see LIONEL ROBBINS, An Essay on the Nature and Significance of Economic Science 4 (Macmillan 1932) ("The definition of Economics which would probably command most adherents . . is that which relates it to the study of the causes of material welfare.").

200. See 15 U.S.C. $\S 1$ (2012) (prohibiting restraints "of trade or commerce"); id. $\S 2$ (banning monopolization or attempted monopolization of "any part of . . . trade or commerce"); see also John M. Newman, Antitrust in Zero-Price Markets: Foundations, 164 U. PA. L. Rev. 149, 159-60 (2015) (analyzing whether zero-price products constitute "trade or commerce" under the Sherman Act).

201. Missouri v. Nat'l Org. for Women, Inc., 620 F.2d 1301 (8th Cir. 1980).

202. Id. at $1302-03$.

203. See id. at 1311-12; see also id. at 1319 ("We hold today that the Sherman Act does not cover NOW's boycott activities ....").

204. See NAACP v. Claiborne Hardware Co., 458 U.S. 886, 914 (1982) ("[T]he purpose of petitioners' campaign was not to destroy legitimate competition. Petitioners sought to vindicate rights of equality and of freedom that lie at the heart of the Fourteenth Amendment itself.").

205. JES Props., Inc. v. USA Equestrian, Inc., No. 802CV1585T24MAP, 2005 WL 1126665 (M.D. Fla. May 9, 2005). 
The governing body issued a rule - subsequently challenged as a restraint of tradegranting "officially recognized" status to same-day shows only when the shows were to take place more than 250 miles apart. ${ }^{206}$ The district court located a valid procompetitive justification in the fact that the restraint "promote[d] the health and welfare of the horses." ${ }^{07}$ It goes nearly without saying that these goals are unrelated to consumer welfare or the economic conception of market failure. ${ }^{208}$

Similarly, in Brown University, the Third Circuit was hospitable to what could be viewed as a non-welfare justification. ${ }^{209}$ At issue was an agreement among a group of Ivy League colleges to award financial aid only on the basis of need and to ensure that aid offers would be comparable across colleges. ${ }^{210}$ In its defense, MIT (the only college that proceeded to trial) argued that the restraint facilitated access to education for financially disadvantaged students. The court credited this justification, in a decision that attracted substantial criticism. ${ }^{211}$ MIT's argument—noble though it may have been - was unrelated to an economic market failure. ${ }^{212}$ To be sure, the court attempted to dress this justification in the language of "consumer choice." ${ }^{213}$ But the restraint did not create a new product, thereby increasing "consumer choice" as that term is used in the antitrust context. ${ }^{214}$

206. Id. at $* 2 \&$ n. 3 .

207. Id. at*16 (emphasis added).

208. One could argue that an externality is at play, but it is, at best, not the sort of externality contemplated by antitrust law and economics. See, e.g., JEAN TIROLE, THE THEORY OF INDUSTRIAL ORGANIZATION $7 \mathrm{n} .18$ (1988) ("An externality arises when the consumption of a good by a consumer directly affects the welfare of another consumer, or when a firm's production affects other economic agents." (emphasis added)). The nature of those affected is the key distinction. Antitrust law can properly recognize (e.g.) investments in promotional materials as creating an externality because such investment directly affects other economic agents. By way of contrast, an owner's behavior may detrimentally affect her horse's health, but that "cost" is not an imposed as an "externality" in the antitrust sense of the term, even though a layperson might (perhaps understandably) view such harm as an externalized cost.

209. United States v. Brown Univ., 5 F.3d 658 (3d Cir. 1997).

210. Id. at 662 .

211. See, e.g., Seitz, supra note 196, at 427 ("Allowing courts to consider social, noneconomic justifications injects an unacceptable level of politics and personal opinion into antitrust analysis.").

212. It is also possible to conceive of MIT's argument as market-failure-based, although doing so requires admitting that irrational behavior is a real phenomenon, a notion that is anathema to orthodox law-and-economics theorists. Students benefit from a diverse educational environment, yet students (particularly nondiverse students) are irrationally unwilling to pay higher prices in exchange for a higher-quality education. MIT did not clearly make this case, however, in what may have been a strategic decision to avoid the hot-button topic of irrational behavior. A subsequent paper by this Author explores whether alleviating behavioral market failures is a cognizable justification. See Newman, supra note 166.

213. Brown Univ., 5 F.3d at 675 (citing NCAA v. Board of Regents of Oklahoma, 468 U.S. 85,101 (1984), for the proposition that consumer choice can be a valid procompetitive justification).

214. NCAA, upon which the Third Circuit relied, was addressing a market (amateur collegiate sports) in which some horizontal restraints were necessary in order for the product to be offered at all. 468 U.S. at 101. 
Most recently, in $O^{\prime}$ Bannon $v$. NCAA, the Ninth Circuit waffled between treating a justification under the rubric of market failure or through a non-welfare lens-but appeared ready to credit the justification either way. ${ }^{215}$ There, the challenged restraint was an NCAA rule prohibiting member schools from compensating student-athletes for the use of their names, images, and likenesses. ${ }^{216}$ The Ninth Circuit affirmed the district court's holding that, by preserving "amateurism," the rule could procompetitively increase consumer (i.e., viewer) demand. ${ }^{217}$

It is possible to view this holding as an application of the market-failure approach. Markets can fail where a given course of action is immediately surplus-maximizing for an individual group member, yet, when undertaken by the entire group, leaves all group members worse off. An individual school may be incentivized to pay its own athletes in order to produce a winning team. But other schools would then be incentivized to follow suit, even if the resulting shift away from amateurism would reduce overall demand for the product. ${ }^{218}$ In other words, individually rational choices could result in all schools producing a more costly, yet less desirable, product.

But the Ninth Circuit in $O^{\prime}$ Bannon also came quite close to blessing amateurism per se, as if amateurism carries intrinsic benefits unrelated to efficiency. ${ }^{219}$ The appellate panel fretted that "the district court ignored that not paying student-athletes is precisely what makes them amateurs" 220 and that paying players any amount would remove all "basis for returning to a rule of amateurism," transforming college football into "minor league football." 221 But the court did not explain why-in terms of consumer welfare - that state of affairs would be undesirable.

Decisions like these represent bad law and bad policy. Doctrinally, they represent an unwarranted deviation from established precedent. ${ }^{222}$ As the foregoing demonstrates, only those restraints that alleviate an economic market failure are cognizable as procompetitive justifications. Proper rule of reason analysis therefore does not recognize non-welfare justifications as valid. In fact, as most readers have likely already concluded, the name is something of a misnomer: as part of a rule of reason analysis, these "justifications" are anything but. ${ }^{223}$

Modern antitrust law's approach to non-welfare justifications represents a balanced compromise. On the one hand, the antitrust enterprise seeks to further its consensus goal of promoting consumer welfare. On the other, it should not do so ad

215. See 802 F.3d 1049 (9th Cir. 2015).

216. Id. at 1052 .

217. Id. at 1059 .

218. See generally Stucke, supra note 87, at 187-90 (describing various examples of divergence between individual and group interests).

219. In this way, the Ninth Circuit's opinion echoed Justice White's dissent in NCAAv. Board of Regents of Oklahoma, which argued in favor of recognizing "noneconomic values like the promotion of amateurism." 468 U.S. 85, 134 (1984) (White, J., dissenting).

220. O'Bannon, 802 F.3d at 1076 (emphasis in original).

221. Id. at 1078-79.

222. See generally AREEDA \& HovenKAMP, supra note 2, 262 (summarizing cases holding that noncommercial activities are immune from antitrust liability).

223. Hence the scare quotes in the title of this Section. 
infinitum - there are other goals than these, ${ }^{224}$ and a single-minded pursuit of economic welfare may have the perverse effect of leaving society worse off. Antitrust doctrinally recognizes the need for balance by immunizing truly nonwelfaremotivated, or "noncommercial," conduct, as did the Missouri v. NOW court. ${ }^{225}$ Extending such comity to the second step of a full-scale rule of reason analysis, however, would upset that careful balance.

Crediting non-welfare justifications during rule of reason analyses creates awkward, and essentially intractable, commensurability problems. Cases that proceed to the procompetitive-justifications stage can already present difficult tradeoffs: how, for example, should a court balance quality improvements against price increases? ${ }^{226}$ But if such cases are difficult, adding social and moral considerations to the mix would make them nigh impossible. ${ }^{227}$ How is a generalist court supposed to weigh improved horses' health against an increase in horse show ticket prices? How does increasing access to prestigious colleges for financially disadvantaged students stack up against higher tuition prices to other students? What is the value of "amateurism" as a virtue unto itself, and how does it compare to lower wages for student-athletes? These questions are alien to antitrust law and economics.

Such policy questions are better answered by the legislative branch. Indeed, that is exactly what Congress did in response to the Justice Department lawsuit underlying Brown University. In 1992, the same year the Third Circuit's decision was issued, Congress enacted an antitrust exemption for the specific conduct at issue in that case. ${ }^{228}$ The exemption has subsequently been extended repeatedly, demonstrating that Congress is capable of intervening if and when necessary. ${ }^{229}$

\section{ERROR-COST ANALYSIS}

We have seen that the market-failure approach is correct as a purely doctrinal matter. But does it also function better than the alternatives? The modern antitrust enterprise is concerned with the social costs of erroneous decisions. ${ }^{230}$ Failures to

224. Cf. Stephen King, The Gunslinger 266 (2003) ("Go then, there are other worlds than these.").

225. See Missouri v. Nat'l Org. for Women, Inc., 620 F.2d 1301 (8th Cir. 1980).

226. Allensworth, supra note 4 , at 4 ("[C]ompetition-whether defined as a process or as a set of outcomes associated with competitive markets-is multifaceted. Antitrust law often must trade off one kind of competition for another, or one salutary effect of competition (such as price, quality or innovation) for another. And in so doing, antitrust courts must make judgments between different and incommensurate values.").

227. If, as Allensworth points out, trading off price and quality effects is difficult, the tradeoffs discussed above would, indeed, seem nearly impossible.

228. See 154 Cong. Rec. 22,817 (2008) (statement of Rep. Smith) ("This exemption originated because Congress disagreed with a suit brought by the Department of Justice against nine colleges for their efforts to use common criteria to assess each student's financial need.").

229. The JES Properties litigation likewise reached its ultimate conclusion via legislative action, though somewhat more indirectly. On appeal, the Eleventh Circuit affirmed the district court's holding that the defendants were granted implied antitrust immunity by the Ted Stevens Olympic and Amateur Sports Act. JES Props., Inc. v. USA Equestrian, Inc., 458 F.3d 1224 (11th Cir. 2006).

230. See Easterbrook, supra note 24. 
condemn anticompetitive behavior (false negatives) reduce welfare, as do decisions that condemn procompetitive behavior (false positives). All else equal, the optimal approach to procompetitive-justification analysis is the one that most effectively minimizes such error costs. As the following discussion demonstrates, the marketfailure approach does so.

\section{A. Competitive Process: Imprecision and False Positives}

In addition to the anachronistic Competitive Process Era decisions, the Court's more modern rule of reason jurisprudence occasionally refers to restraints' "impact on competition" 231 and "the competitive process." 232 Scholar-enforcer Gregory Werden locates in such references and in Professional Engineers a "single-minded focus on the competitive process." 233 Under this view, because "Congress has established a legislative policy favoring competition," ${ }^{234}$ defendants cannot justify restraining the competitive process by pointing to failures of that same competitive process. Other scholars have descriptively and prescriptively argued in favor of a competition- or competitive-process-based approach to antitrust analysis. ${ }^{235}$

But without more clarity, the competitive-process approach offers far too little guidance. As a result, it carries substantial risk of producing both false negatives and false positives. ${ }^{236}$ Although the modern Court sometimes invokes the virtues of "competition" and the "competitive process," ${ }^{237}$ it has never explained what those "wonderfully ill-defined" terms actually mean. ${ }^{238}$ Werden argues forcefully for the competitive-process approach without ever seeming to define "competitive process." 239 How is competitive-process analysis supposed to proceed? Werden

231. FTC v. Ind. Fed'n of Dentists, 476 U.S. 447, 458 (1986) ("[T]he test of legality is whether the restraint imposed is such as merely regulates and perhaps thereby promotes competition or whether it is such as may suppress or even destroy competition.").

232. NYNEX Corp. v. Discon, Inc., 525 U.S. 128, 135 (1998).

233. Werden, supra note 9 , at 732-37.

234. Hammer, supra note 24 , at $854-55$. Hammer does not subscribe to this view, but merely observes its existence.

235. See, e.g., Orbach, supra note 97; Stucke \& Ezrachi, supra note 98 (arguing for a return to the "competition ideal").

236. Bork criticized "competition" on these grounds. See BorK, supra note 79, at 58 ("The fact that judges, like the rest of us, have used the word to mean very different things has resulted in the fruitless discourse of men talking past each other.").

237. See supra note 194 (explaining that these references are best understood in the unique context of "antitrust injury" and not as a return to a purely competitive-process-based approach).

238. Indeed, as Hammer observes, "[c]ompetition is a wonderfully ill-defined term." Hammer, supra note 24 , at 850 n.3.

239. The clearest definition this Author could locate is as follows:

$[R]$ ules designed to ensure the control of economic power that is incompatible with the social and political values of a just community, the integrity of individualism in that community, and the ideal of equality of economic opportunity. . . [This approach] is often identified by the concept of a 'competitive process' and derives its meaning from a multiplicity of social 
admits that restraints are sometimes justified where "they make the market work better." ${ }^{40}$ But what does "better" mean in this context? If it means simply "more efficient," ${ }^{241}$ then the competitive-process approach adds no value. Werden posits that "a defendant cannot justify a restraint on the basis that it promotes social or consumer welfare in any way other than through promoting competition" ${ }^{242}$-but admits that "[n]evertheless, a restraint likely would be permitted if the factfinder determined it was necessary to public health or safety." ${ }^{243}$ Why would this be so, if there were not some value at play other than the "competitive process" (or, at the very least, some other chosen means for promoting that value)?

Perhaps "competition" means a state of atomistic rivalry in the spot market, to be pursued as an end unto itself $\mathrm{f}^{244}$ or in order to vindicate the vaguely defined grouping of rights discussed above. ${ }^{245}$ During the Competitive Process Era, nearly every restraint was condemned, ${ }^{246}$ suggesting that not much more than standard, one-off contracts could escape liability. That approach almost certainly produced excessive

sciences including history, economics, philosophy, political science, and sociology.

John J. Flynn, Antitrust Policy and the Concept of a Competitive Process, 35 N.Y. L. SCH. L. REv. 893, 897 (1990). While arguably an apt description of the Sherman Act's overarching goals, it is difficult to ascertain how this approach would guide justification analysis in a given case.

240. Werden, supra note 9, at 754 (emphasis added).

241. There is some suggestion of this-Werden concludes that because "vertical restraints hold the promise of increasing a firm's efficiency and enabling it to compete more effectively, ... they normally do not harm the competitive process." Id. at 750 (internal quotation marks omitted).

242. Id. at 753 .

243. Id. at 753 n. 258

244. See, e.g., Alan J. Meese, In Praise of All or Nothing Dichotomous Categories: Why Antitrust Law Should Reject the Quick Look, 104 GEO. L.J. 835, 836 (2016) ("During antitrust's 'inhospitality era,' courts declared . . . agreements unlawful per se, drawing upon economic theory hostile to various contracts that, although not naked, thwarted atomistic competition by restraining the conduct of trading partners."); Alan J. Meese, Robert Bork's Forgotten Role in the Transaction Cost Revolution, 79 ANTITRUST L.J. 953, 954 (2014) (describing the "inhospitality tradition of antitrust: an instinctive hostility to business conduct other than moment-by-moment rivalry in the spot market" (internal quotation marks omitted)).

245. See supra notes 104-07 and accompanying text. Stucke and Ezrachi appear to endorse a vision along these lines, advocating a "competition ideal" as a replacement for the consumer welfare standard. See Stucke \& Ezrachi, supra note 98 ("The competition ideal was the belief, in line with democratic principles, in dispersing economic and political power from the hands of a few, to foster greater opportunities to compete, improve, and win." (emphasis in original)). Intriguingly, Stucke and Ezrachi cite to Hayek as a supporter of this view: as they point out, Hayek's The Road to Serfdom observes that "in order that competition should work beneficially, a carefully thought-out legal framework is required." Id. (quoting FRIEDRICH A. HAYEK, THE RoAd TO SERFDOM 45 (condensed version 1999)). Hayek goes on to state that "[t]he successful use of competition does not preclude some types of government interference," and that "break[ing] up monopolies" is a task that "provide[s] a wide and unquestioned field for state activity." HAYEK, supra, at 46.

246. See, e.g., Werden, supra note 9, at 729 ("Northem Pacific began an era during which the Supreme Court saw a 'pernicious effect' in every restraint it examined."). 
false positives - courts using it systematically condemned beneficial restraints. In fact, the entire agenda of the Chicago School of antitrust can largely be distilled into one objective: to critique the rules crafted during the Competitive Process Era on the grounds that they excessively condemned welfare-enhancing conduct. ${ }^{247}$ That objective was, of course, largely achieved. A variety of restraints that reduce "competition-as-atomistic-rivalry," even horizontal price-fixing 248 or marketallocation $^{249}$ agreements, can potentially pass muster under modern antitrust law.

Thus, the competitive-process approach is either so ill-defined as to be effectively devoid of content, or it produces results so one-sided that the Court abandoned it after a brief dalliance. If the former, then the competitive-process approach will very likely yield a great deal of both false positives and negatives, randomly distributed. If the latter, it will yield —and, during the Inhospitality Era, did yield ${ }^{250}$ — very few false negatives but an inordinate amount of false positives, skewing the field systematically in favor of plaintiffs. Either way, this approach fails to perform its supposed task of sorting legal ("reasonable") from illegal ("unreasonable") conduct. ${ }^{251}$

Even if Congress intended some ill-defined conception of "competition" to serve as the overarching goal of the antitrust laws, the decision rules for promoting that goal may - and, it seems, must-nonetheless comprise something other than competition itself. Some standard is needed in order to distinguish between reasonable and unreasonable restraints. The undefined competitive-process approach fails to do so.

247. See, e.g., BoRK, supra note 79 , at 7 ("Certain of its doctrines preserve competition, while others suppress it, resulting in a policy at war with itself.").

248. Broad. Music, Inc. v. CBS, Inc., 441 U.S. 1 (1979); Christopher Leslie, Comment, Achieving Efficiency Through Collusion: A Market Failure Defense to Horizontal PriceFixing, 81 CALIF. L. REV. 243, 263 (1993) (calling the joint license in BMI "the essence of price-fixing"); see also O'Bannon v. NCAA, 802 F.3d 1049 (9th Cir. 2015) (recognizing some procompetitive justifications for a horizontal agreement to fix prices paid by universities for the right to student-athletes' names, images, and likenesses).

249. See Polk Bros., Inc. v. Forest City Enters., Inc., 776 F.2d 185 (7th Cir. 1985) (productmarket allocation); $c f$. United States v. Kemp \& Assocs., Inc., No. 2:16-CF-403DS, 2017 WL 3720695 (D. Utah June 22, 2017) (holding that the rule of reason applied to an alleged customer allocation scheme that the Government had sought to prosecute criminally).

250. E.g., Meese, supra note 57, at 146.

251. See, e.g., Standard Oil Co. v. United States, 221 U.S. 1, 60 (1911) ("[A]s the contracts or acts embraced in [Sherman Act $\S 1$ ] were not expressly defined, since the enumeration addressed itself simply to classes of acts, those classes being broad enough to embrace every conceivable contract or combination which could be made concerning trade or commerce or the subjects of such commerce, and thus caused any act done by any of the enumerated methods anywhere in the whole field of human activity to be illegal if in restraint of trade, it inevitably follows ... that the standard of reason which had been applied at the common law and in this country ... was intended to be the measure used for the purpose of determining whether, in a given case, a particular act had or had not brought about the wrong against which the statute provided." ). 


\section{B. Type of Effect: Imprecision, False Positives, and False Negatives}

The type-of-effect approach fares no better. In addition to being out of step doctrinally, it yields incorrect outcomes in at least three ways. The first yields excessive false positives. The second produces excessive false negatives. The third creates confusion, which tends to increase the likelihood of both types of error.

First, the type-of-effect approach will cause analysts to mistakenly reject justifications that should be recognized as valid, causing false-positive errors. Some justifications enhance welfare, yet cause a type of effect that is not included on the usual checklists. "Higher output," for example, is universally included as a good type of effect. ${ }^{252}$ (Recall that some analysts even argue higher output is the only good type of effect.) Yet certain restraints of trade can increase welfare by lowering output. A type-of-effect analyst would wrongly condemn such restraints.

Consider the restraints on false and misleading advertising at issue in California Dental. ${ }^{253}$ Deception can increase output of the deceiver's product, yet reduce consumer welfare. The U.S. Supreme Court appeared to recognize as much, noting that the challenged restraints "could have different effects from those 'normally' found in the commercial world, even to the point of promoting competition by reducing the occurrence of unverifiable and misleading across-the-board discount advertising." 254 Misleading advertisements regarding discounts could —indeed, are designed to-increase output. Restraints on misleading advertisements may decrease output, yet increase consumer welfare. As a result, the Court held that such restraints may be justified. Yet a lower court or enforcement agency applying the type-of-effect approach would likely condemn the restraints, following the simplistic logic that all output-reducing restraints are anticompetitive.

A restraint may also alleviate a market failure caused by overconsumption, reducing output of the relevant product while increasing consumer welfare. Suppose that an organization made up of higher educational institutions (law schools, perhaps) is tasked with overseeing its own members' accreditation status. Member schools face mandatory public disclosure of all information relevant to prospective students' cost-benefit analysis (tuition, employment rates, debt load, and the like). Nonetheless, some students irrationally attend a subpar institution that offers little hope of employment in exchange for a six-figure price tag. ${ }^{255}$ Eventually, the

252. At the very least, this Author is not aware of any type-of-effect checklist that does not include higher output as a valid justification.

253. California Dental Ass'n v. FTC, 526 U.S. 756 (1999).

254. Id. at $773-74$.

255. Some argue that (some) law schools fit this description. See, e.g., Paul Campos, The Law-School Scam, ATLANTIC, Sept. 2014 ("This world [of for-profit legal education] is one in which schools accredited by the American Bar Association admit large numbers of severely underqualified students; these students in turn take out hundreds of millions of dollars in loans annually, much of which they will never be able to repay."); Michael Simkovic \& Frank McIntyre, The Economic Value of a Law Degree 1 (Harv. L. Sch. Ctr. on the Legal Profession, Research Paper No. 2013-6, 2013), https://papers.ssm.com/sol3/papers.cfm?abstract _id=2250585 [https://perma.cc/Z4MP-A5T2] "Legal academics and journalists have marshaled statistics purporting to show that enrolling in law school is irrational."). Behavioral economics research on consumers' intertemporal irrationality could offer a ready explanation 
accrediting organization strips the subpar school of its accreditation, effectively foreclosing that competitor from the market. The accrediting organization's conduct could invite antitrust litigation, raising the question of whether it is justified. ${ }^{256}$ The restraint likely reduces output of the relevant product, and would therefore be condemned as anticompetitive under the type-of-effect approach. Yet accreditation decisions like this can rather obviously benefit consumers.

As a final example, consider the U.S. chemical industry's "Responsible Care" initiative. ${ }^{257}$ Under this initiative, members of a trade association agree to reduce environmental pollution, ${ }^{258}$ an externality that causes market failures. ${ }^{259}$ Such efforts almost certainly decrease output, yet the U.S. government actively encourages them. ${ }^{260}$ In some market contexts, it seems lower output is a socially desirable result.

An analyst employing the type-of-effect approach would likely condemn the restraints in each of these cases. Each tends to lower output, a prototypical "anticompetitive effect." 261 But such restraints are justifiable; they alleviate market failures. ${ }^{262}$ Holding otherwise is, as a doctrinal matter, incorrect. Thus, for example,

for such behavior. Ted O'Donoghue \& Matthew Rabin, Doing It Now or Later, 89 AM. ECoN. REV. 103, 103 (1999).

256. Cf., e.g., Mass. Sch. of Law at Andover, Inc. v. ABA, 846 F. Supp. 374 (E.D. Pa. 1994) (dismissing in part a complaint by an unaccredited law school against the American Bar Association (ABA), the primary accreditation body for U.S. law schools, alleging that several ABA accreditation standards were anticompetitive). On this topic generally, see Lao, supra note 24 .

257. Responsible Care, AM. CHEM. COUNCIL, https://responsiblecare.americanchemistry .com/ [https://perma.cc/EDZ8-FWPY]; see also Keith Brouhle, Charles Griffiths \& Ann Wolverton, The Use of Voluntary Approaches for Environmental Policymaking in the U.S. (Nat'1 Ctr. for Envtl. Econ., Working Paper No. 04-05, 2004), https://www.epa.gov/sites /production/files/2014-12/documents/the_use_of_voluntary_approaches_for_environmental _policymaking.pdf [https://perma.cc/9LP6-U2יPJ].

258. AM. Chem. Council, supra note 257.

259. See, e.g., Boris N. Mamlyuk, Analyzing the Polluter Pays Principle Through Law and Economics, $18 \mathrm{SE}$. ENvTL. L.J. 39 (2009).

260. Brouhle et al., supra note 257.

261. See Bork, supra note 79 , at 122 ("The task of antitrust is to identify and prohibit those forms of behavior whose net effect is output restricting ....").

262. See supra Section II.C. An interesting—and important-question, though one beyond the scope of this Article, is whether a restraint that lowers welfare in the relevant market can ever be justified by virtue of the fact that it increases welfare overall. Put another way, is the relevant market the exclusive arena within which effects are to be analyzed? Or is it, for lack of a better word, permeable? Werden persuasively suggests that market definition plays a broad role in constructing the "antitrust narrative" at issue in litigation. Gregory J. Werden, Why (Ever) Define Markets? An Answer to Professor Kaplow 14 (unpublished draft), https://papers.ssrn.com/sol3/papers.cfm?abstract_id=2004655 [https://perma.cc/VJW5 -4 PEZ]. Perhaps, then, the relevant market does not dictate the precise metes and bounds of every facet of a given antitrust case. And if that is true, then the environmental-pollution justification at play in the hypothetical above could (potentially) be cognizable. If not, however, the justification would likely be disallowed. Suppose that a given factory produces widgets while polluting a river, harming downstream residents. Such harms would be invisible under a pure partial-equilibrium analysis: they occur outside the relevant market for widgets. And a justification comprising the reduction of such harms would fail. 
the Supreme Court reversed the Ninth Circuit's California Dental decision, which had invoked the type-of-effect approach to condemn the challenged restraint. ${ }^{263}$ In error-cost terms, the type-of-effect approach produces excessive false positives, thereby harming those whom the antitrust laws are supposed to protect.

Second, the type-of-effect approach may lead courts to credit justifications that should be rejected. By inviting an overly simplistic, surface-level version of justification analysis, the type-of-effect approach can cause courts to skip over crucial steps and wrongly credit sham justifications. Such decisions represent false negatives.

In SCFC ILC, for example, the Tenth Circuit incorrectly credited a defendant's proffered "free riding" justification. ${ }^{264}$ Visa, then a horizontal association of banks, excluded Sears (which issued the competing Discover card) from issuing Visa-brand cards. ${ }^{265}$ Visa claimed its restraint was necessary to prevent Sears from "free riding." Yet it was entirely unclear how the restraint could have done so - or even upon what, exactly, Sears could have taken a free ride. ${ }^{266}$ Nonetheless, the Tenth Circuit simply accepted Visa's invocation of "prevent[ing] free riding" as a shibboleth. ${ }^{267}$ The court's opinion carries throughout the hallmarks of type-of-effect analysis. ${ }^{268}$ It reasoned as follows: (1) "concern[] about free-riding" is one of the type of effects that justify restraints, (2) Visa argued that its restraint prevented free riding, so (3) the restraint was justified. ${ }^{269} \mathrm{~A}$ few years later, the government sued to enjoin Visa's exclusionary restraint. In a more rigorous decision that was upheld by the Second Circuit, the district court rejected Visa's proffered justification, ${ }^{270}$ reinforcing the conclusion that $S C F C$ ILC was incorrectly decided.

Third, the type-of-effect approach can introduce unnecessary confusion into antitrust doctrine, increasing the likelihood of both types of error. If assembling a proper checklist of "procompetitive benefits" is the starting point, cases like Professional Engineers become difficult - if not impossible - to synthesize. This is why some analysts present the case as a "conundrum." 271 The Professional Engineers Court seemed to suggest that "enhanced public safety and increased quality ... [a]re not the sort of virtues courts should consider." 272 Yet such claims - particularly those

263. Cal. Dental Ass'n v. FTC, 128 F.3d 720, 728 (9th Cir. 1997) ("These restrictions are in effect a form of output limitation, as they restrict the supply of information about individual dentists' services."), rev'd, 526 U.S. 756 (1999).

264. See SCFC ILC, Inc. v. Visa USA, Inc., 36 F.3d 958 (10th Cir. 1994).

265. Visa also excluded bank issuers that issued American Express cards. Id. at 961.

266. See AREEDA \& HovenKAMP, supra note $2,92223 \mathrm{~b} \&$ nn.3-4.

267. See generally Oliver E. Williamson, Why Law, Economics, and Organization?, 1 ANN. REv. L. \& Soc. ScI. 369, 383 (2005) ("Finally, unspecific free-rider claims are too often used as a shibboleth.").

268. The court described $B M I$, for example, as crediting "the efficiency justification of increasing ... aggregate output." SCFC ILC, 36 F.3d at 964.

269. Id.

270. United States v. Visa USA, Inc., 163 F. Supp. $2 d 322$ (S.D.N.Y. 2001), aff'd, 344 F.3d 229 (2d Cir. 2003).

271. Sullivan ET AL., supra note 7, § 5.3f, at 223.

272. Meese, supra note 145 , at 1788 ("Simply put, the supposed benefits of the restriction on price competition-enhanced public safety and increased quality-were not the sort of virtues courts should consider when conducting a rule of reason analysis."); see also SULLIVAN 
involving higher quality - have repeatedly met with approval from subsequent courts. The Court itself extolled higher quality as a virtue in Leegin. ${ }^{273}$ Since different market-failure correctives can push output, quality, etc. in different directions, the type-of-effects approach creates unnecessary confusion over which types are actually valid.

This mischief can be seen at play in Law v. NCAA. ${ }^{274}$ The Tenth Circuit's checklist of valid justifications included "creating operating efficiencies." 275 Yet the same opinion also identified "cost savings" as a categorically invalid justification. ${ }^{276}$ One wonders: What are "operating efficiencies" if not a type of "cost savings"? Other courts have used the terms interchangeably. ${ }^{277}$ And guidelines jointly issued by the DOJ and FTC explicitly contemplate "cost savings" as a valid justification. ${ }^{278}$ What is a court to make of this mess? Is "cost savings" on the valid checklist? The invalid blacklist? Both?

As a final nail in the coffin, consider the nearly nonsensical analysis in AnheuserBusch, a case involving exclusive territorial restrictions imposed by a liquor manufacturer on its wholesalers. ${ }^{279}$ By way of justification, the manufacturer identified several types of "procompetitive effects," including increased wholesaler investments in "cosmetics." ${ }^{280}$ The plaintiff argued in response that cosmetic features like "uniforms and newly painted trucks are not procompetitive." 281 Precedent offered the court no guidance as to whether those were, in fact, a valid type of effect. As a result, the court was left to observe (citing no authority) that "given a choice people buy a clean or smartly dressed or groomed product ahead of one that presents a dirty or disheveled appearance." 282 While that observation may generally be accurate, it was a non sequitur: it did not explain why the unrestrained market would have failed to optimize product quality or how the restraint could have alleviated such a failure. Nonetheless, the justification was held to be valid. ${ }^{283}$ Such unfocused

ET AL., supra note 7, $\S 5.3 \mathrm{f}$, at 223 (associating Professional Engineers with the proposition that "public health and welfare cannot be counted as independent benefit categories."). Later in the same article, Meese urges a reading that aligns with the present one: "[W]hen read properly, Professional Engineers allows defendants to escape per se condemnation by adducing a plausible argument that, absent the restriction, one or more departures from the assumptions of perfect competition would lead unbridled rivalry to produce a market failure." Meese, supra note 145, at 1790-91.

273. See Leegin Creative Leather Prods., Inc. v. PSKS, Inc., 551 U.S. 877, 891-92 (2007).

274. 134 F.3d 1010 (10th Cir. 1998).

275. Id. at 1023 .

276. Id. ("C $[\mathrm{M}]$ ere profitability or cost savings have not qualified as a defense under the antitrust laws.").

277. See, e.g., United States v. LTV Corp., No. 84-884, 1984 WL 21973, at *10 (D.D.C. Aug. 2, 1984).

278. U.S. Dep't of Just. \& Fed. Trade Comm'n, Statements of Antitrust ENForcement Policy in Heal th Care 20, 21, 80, 97, 123, 134 (1996).

279. New York v. Anheuser-Busch, Inc., 811 F. Supp. 848 (E.D.N.Y. 1993)

280. Id. at 876 .

281. Id.

282. Id. at 877 .

283. Id. The court need not have reached this result, since it also found that the defendant lacked market power. See Carrier, supra note 4, at 1276. 
"analysis" speaks for itself. An antitrust enterprise concerned with minimizing error costs cannot use the type-of-effect approach as the linchpin of justification analysis.

\section{The Market-Failure Approach Minimizes Errors}

The market-failure approach offers consequentialist advantages over alternative approaches. The modern antitrust enterprise generally seeks to minimize error costs. ${ }^{284}$ The market-failure-based approach is best suited to do so. It is more likely to avoid false positives than the competitive-process approach, and more likely to prevent false negatives than the type-of-effect approach.

As to the former, one need look no further than the Supreme Court's Modern Era jurisprudence to find the market-failure approach being used to correctly reject challenges to beneficial restraints. A competitive-process analysis may well have condemned the joint license in $B M I$, for example-which, after all, involved horizontal price fixing. But, assuming that the goal of antitrust is to promote consumer welfare, such a decision would have constituted an obvious false positive. The $B M I$ Court's market-failure approach avoided that undesirable outcome.

As to the latter, consider SCFC ILC. That court could have avoided its erroneous decision by employing the more rigorous market-failure approach. "Free riding" occurs due to a particular type of market failure: the presence of positive externalities. ${ }^{285}$ With that in mind, the court first should have pointedly asked whether Visa's business model created positive externalities upon which Sears could have taken a free ride. Since that was not the case, the inquiry could (and should) have ended at this point. ${ }^{286}$

The Anheuser-Busch court's analysis could similarly have been improved had it used the market-failure approach. There, wholesalers allegedly needed exclusive territories to prevent rivals from free riding on their investments in various "cosmetics." 287 But do wholesalers' investments in fresh paint for their delivery trucks create any positive externalities upon which rivals could take a free ride? Of course not. By the time a delivery truck arrives, the purchasing decision has already been made. Unlike, for example, a storefront retailer's investment in a knowledgeable sales staff, fresh paint for delivery trucks does not create

284. See generally Easterbrook, supra note 24. For a trenchant critique of error-cost analysis as currently employed by the antitrust orthodoxy, see Jonathan B. Baker, Taking the Error Out of "Error Cost" Analysis: What's Wrong with Antitrust's Right, 80 ANTITRUST L.J. 1 (2015).

285. See, e.g., Tyler Cowen, Public Goods and Externalities, LBRR. ECON. \& LIBERTY: CONCISE ENCYCLOPEDIA ECON., http://www.econlib.org/library/Enc1/PublicGoodsand Externalities.html [https://perma.cc/DXE3-P9Y5] ("[T] he free-rider problem and positive externalities are two sides of the same coin.").

286. Some courts and scholars suggest that free riding on point-of-sale services occurs rarely in practice. See, e.g., Graphic Prods. Distribs., Inc. v. Itek Corp., 717 F.2d 1560, 1576 (11th Cir. 1983); William S. Stewart \& Barry S. Roberts, Viability of the Antitrust Per Se Illegality Rule: Schwinn Down, How Many to Go?, 58 WASH. U. L.Q. 727, 756 (1980) ("Frequently point-of-sale services are unnecessary and the 'free-rider' problem does not actually exist.").

287. New York v. Anheuser-Busch, Inc., 811 F. Supp. 848, 855-56 (E.D.N.Y. 1993). 
externalities. There was no free ride to be had. By prompting such questions, the market-failure approach could have prevented the Anheuser-Busch court from crediting a sham justification.

U.S. judges, as core institutional members of a deep-seated liberal tradition, tend naturally to be skeptical of claims that markets do not work. ${ }^{288}$ Perhaps this tendency helps to explain why modern plaintiffs almost never win rule-of-reason cases. ${ }^{289}$ Antitrust plaintiffs must convince judges that the (restrained) market is not working very well. Often overlooked is the fact that antitrust defendants make a similar claim—one that should invite similar skepticism. An antitrust defendant that proffers a procompetitive justification is, in effect, arguing that the unrestrained market was not working very well. The market-failure approach is likely to prompt more searching judicial analyses of alleged procompetitive justifications.

The market-failure approach also offers greater clarity to those seeking to understand antitrust doctrine. The type-of-effect framework leads to cases like Professional Engineers being treated as a doctrinal "conundrum." ${ }^{290}$ But the proper question is not whether "higher quality" is procompetitive or anticompetitive. That inquiry leads nowhere; authority can be found to support either proposition. Instead, the proper question is whether the challenged restraint alleviated a market failure.

Finally, the market-failure approach refocuses antitrust on its raison d'être. The type-of-effect approach was born out of - and has materially contributed to - an unhealthy obsession with output. ${ }^{291}$ While output effects can be a useful diagnostic tool, they are not, nor should they be, the entirety of antitrust analysis. Sometimes higher output is good. But not always. Externalizing costs, ${ }^{292}$ overconsumption, ${ }^{293}$ deception, ${ }^{294}$ coercion ${ }^{295}$-all can increase output, yet harm consumers and society. Restraints that prevent such conduct may decrease output, yet leave the world a better place. It is high time for the antitrust enterprise to recognize the shortcomings of focusing exclusively on output.

288. See, e.g., Frank H. Easterbrook, Workable Antitrust Policy, 84 MicH. L. REv. 1696, 1701 (1986) (advocating an antitrust program that is "profoundly . . . skeptical of the ability of courts to make things better even with the best data").

289. See Carrier, supra note 42 , at 830 (observing that, during the decade stretching from 1999 to 2009 , defendants won 221 of 222 rule-of-reason cases, a $99.5 \%$ win rate).

290. See Sullivan ET AL., supra note 7, § 5.3f, at 223.

291. Bork, supra note 79, at 122 ("The task of antitrust is to identify and prohibit those forms of behavior whose net effect is output restricting and hence detrimental."); cf. Barak Y. Orbach, The Antitrust Consumer Welfare Paradox, 7 J. COMPETITION L. \& ECON. 133, 153 (2010) ("[A]ntitrust laws appear to welcome low prices regardless of the actual impact on consumer welfare.").

292. See, e.g., Robert S. Pindyck \& Daniel L. Rubinfeld, Microeconomics 646 (7th ed. 2009) ("When firms do not take into account the harms associated with negative externalities, the result is excess production and unnecessary social costs.").

293. See e.g., John M. Newman, Copyright Freeconomics, 66 VAND. L. REV. 1409, 1446 (2013) (discussing overconsumption and hoarding behaviors in the context of "free" digitalmedia products).

294. Patterson, supra note 121.

295. Id. 


\section{ANALYZING PROCOMPETITIVE JUSTIFICATIONS}

As we have seen, the market-failure approach offers superior flexibility and accuracy. But, while market failure has become the touchstone for modern procompetitive-justification analysis, there remains considerable room for improvement. Properly applying the market-failure approach requires a clear analytical framework. ${ }^{296}$ The following discussion explains how best to assess procompetitive justifications.

\section{A. The Three-Step Framework}

It is not enough to ask whether the defendant has offered some justification for its conduct. It is not enough to ask whether the challenged restraint increased or decreased output. And it is not enough to ask whether the defendant has paid lip service to some common cause of market failure (free riding, for example). These questions are either too unfocused or overly simplistic. Instead, when conducted properly, procompetitive justification analysis entails three steps.

First, the defendant must identify a specific cause of market failure. To be a valid starting point, the identified market failure must be well-recognized and wellaccepted. This is a question of antitrust law and economics. If the defendant's proffered justification amounts to nothing more than a claim that its product is not competitive, the analysis can end. The "justification" is baseless: producing unattractive products is not a textbook source of market failure. To the contrary, a restraint that props up demand for such a product reduces welfare. ${ }^{297}$ If, instead, the defendant identifies high transaction costs, free-rider problems, downstream market power, information asymmetries, or another well-established cause of market failure, analysis should proceed to the next step.

Second, the defendant must prove that the relevant market actually failed (or would have failed ${ }^{298}$ absent the challenged restraint. This is a purely factual question. A defendant cannot simply claim, without more, that the market was subject to "some" failure. Specificity is required. A vague claim of "transaction costs" alone, for example, is not enough. Cases like BMI are illustrative: the defendant did not merely claim a "market failure" or even "transaction costs." Instead, it demonstrated that the vast number of sellers and buyers in the relevant market meant that the costs of transacting were prohibitively high relative to the value of the rights at issue. ${ }^{299}$ Similarly, vague claims of "free riding" alone are not

296. The following assumes that the analyst has already assessed whether the defendant's proffered justification has nothing to do with consumer welfare. If so, rule-of-reason analysis may be inappropriate: the challenged conduct may be noncommercial and therefore outside the scope of the antitrust laws.

297. See NCAA v. Bd. of Regents, 468 U.S. 85, 115-16 (1984) (rejecting defendant's argument that restricting output of televised games was necessary to ensure live attendance).

298. Cf. Brief of Respondent at 26, FTC v. Ind. Fed'n of Dentists, 476 U.S. 447 (1986) (No. 84-1809) ("Hopefully, a body count will not be required before health care concerns are considered in a proper rule of reason analysis.").

299. Brief for Petitioners at 23, Broadcast Music, Inc. v. CBS, Inc., 441 U.S. 1 (1979) (Nos. $77-1578,77-1583$ ) ("[T]he transaction costs in obtaining rights to individual songs are 
sufficient. The defendant must prove that its business model produced some positive externality, and that its rivals were able to take a free ride on that externality. Testimony from marketplace participants can shed light on this question, as can econometric evidence. Evidence of the defendant's rationale for adopting the restraint will also be probative. ${ }^{300}$

Third, the defendant must prove that the challenged restraint actually alleviated the market failure. This, too, is a factual question. Of course, the defendant need not show that the restraint entirely cured the relevant market failure. But some showing of alleviation is required. Here again, evidence of the defendant's rationale for imposing the restraint will be probative, though the ultimate question is one of effect, not intent. ${ }^{301}$

As we have seen, restraints of trade that decrease output of the relevant product can be welfare enhancing. ${ }^{302}$ But alleged procompetitive justifications that involve output reductions are particularly suspect: the defendant is alleging that it behaved against its own selfish interest. That said, such justifications are more likely (though certainly not always $)^{303}$ valid where the defendant is a nonprofit entity ${ }^{304}$ or the defendants comprise a majority of nonprofit entities. ${ }^{305}$

In sum, and with these principles in mind, the proper procompetitive-justification inquiry is structured as follows:

1. First, the defendant must identify a specific, well-established cause of market failure.

2. Second, the defendant must prove that the relevant market actually failed (or would have failed) absent the challenged restraint.

3. Third, the defendant must prove that the challenged restraint actually alleviated the market failure.

prohibitively high in relation to the value of the rights.").

300. See United States v. Am. Express Co., 88 F. Supp. 3d 143, 160-62 (E.D.N.Y. 2015), rev'd on other grounds, 838 F.3d 179 (2d Cir. 2016), cert. granted sub nom. Ohio v. Am. Express Co., 138 S. Ct. 355 (2017).

301. AREEDA \& HoveNKAMP, supra note 2, 1506.

302. See supra notes $253-61$ and accompanying text.

303. See, e.g., United States v. N.D. Hosp. Ass'n., 640 F. Supp. 1028 (D.N.D. 1986) (striking down a horizontal agreement among nonprofit, charitable institutions).

304. As to nonprofits, the general consensus view appears to echo Judge Posner's observation in Hospital Corporation of America v. FTC: "The adoption of the nonprofit form does not change human nature ..." 807 F.2d 1381, 1390 ( 7 th Cir. 1986) (affirming the FTC's decision to block a hospital merger). Such institutions are still, by and large, presumed to be rational and profit-maximizing. Cf. id. at 1390-91; N.D. Hosp. Ass'n, 640 F. Supp. 1028 (striking down a horizontal agreement among nonprofit, charitable institutions). But see FTC v. Butterworth Health Corp., 946 F. Supp. 1285, 1296-97 (W.D. Mich. 1996) (relying, in the context of an FTC challenge to a proposed hospital merger, on the nonprofit status-and attendant nonstandard incentives - of both merging parties to conclude that harm to competition was unlikely).

305. Cf. N.C. State Bd. of Dental Exam'rs v. FTC, 135 S. Ct. 1101 (2015) (holding that a state licensing board comprising a majority of active market participants did not receive state action immunity from antitrust liability). 
This systematic framework facilitates accurate analysis, thereby minimizing error costs. It also increases the transparency and clarity of judicial decision-making. As the leading treatise notes, these are particularly important and noble goals in antitrust law, largely a common law discipline. ${ }^{306}$

\section{B. Case Comparison: Increasing Rigor, Improving Outcomes}

To illustrate how the three-step market-failure approach can facilitate decisionmaking in practice, consider a pair of antitrust cases, both involving credit card network markets. The first is $S C F C I L C$, which relied on the simplistic type-of-effect approach and reached an erroneous decision. The second is the district court's opinion in American Express, which employed the market-failure approach to correctly assess two proffered justifications.

In SCFC ILC, as we have seen, the Tenth Circuit wrongly credited a defendant's sham "free rider" justification. The resulting false positive proved costly: it required DOJ to relitigate essentially the same case a few years later in order to correct the error, necessitating a substantial outlay of societal resources. ${ }^{307}$ Consumer welfare suffered in the interim. All of this could have been avoided had the Tenth Circuit correctly employed the three-step approach. The analysis could have ended at the second step: the relevant market did not actually exhibit the alleged failure.

Compare that with the Eastern District of New York's decision in American Express. There, the district court was presented with two proffered justifications. ${ }^{308}$ Neither was, on its face, an obvious candidate for rejection - but both were, in fact, baseless. Employing a rigorous market-failure approach, the district court reached the correct decision on both counts.

At issue were a credit card network's contractual restraints that prevented merchant customers from, among other things, communicating truthful pricing information to their clientele. ${ }^{309}$ American Express's first justification was that its restraints were necessary to preserve its "differentiated" business model, which depended on extracting high fees from its merchant customers. ${ }^{310}$ The court described at length American Express's various complex arguments in favor of this justification, noting that they were "intuitively appealing." 311 But, as the court

306. See, e.g., AREEDA \& HovenkAMP, supra note 2 , 1500 ("By exposing their reasoning, judges and commentators are subjected to others' critical analyses, which in turn can lead to better understanding for the future.").

307. See United States v. Visa U.S.A., Inc., 163 F. Supp. $2 d 322$ (S.D.N.Y. 2001), aff'd, 344 F.3d 229 (2d Cir. 2003).

308. United States v. Am. Express Co., 88 F. Supp. 3 d 143 (E.D.N.Y. 2015), rev'd on other grounds, 838 F.3d 179 (2d Cir. 2016).

309. Id. at 165 .

310. Id. at 225. The relevant market(s), however defined, in which credit card networks operate appear to be less than perfectly competitive by a wide margin. See, e.g., Rory Van Loo, Making Innovation More Competitive: The Case of Fintech, 65 UCLA L. REv. 232, 245-46 (2018) (drawing on natural experiments to argue that credit card markets exhibit "insufficient competition").

311. American Express, 88 F. Supp. 3d at 227. 
pointed out, "assuming American Express actually offers premium value to its merchants, the market will tolerate ... a premium price for its network services." 312

In short, American Express simply failed to identify a market failure. Its arguments, stripped down to their essence, were similar to the argument in NCAA $v$. Board of Regents that restricting output of televised games was necessary to protect live attendance ${ }^{313}$ As the U.S. Supreme Court recognized, defendants cannot escape liability by arguing that their products are "insufficiently attractive to consumers" and need to be insulated from competition. ${ }^{314}$ Unattractive products going unsold is not a valid reason to restrain a market. In fact, a restraint that artificially props up demand for an unattractive product by stifling the flow of truthful information is anticompetitive, not procompetitive-it causes a market failure. ${ }^{315}$ American Express was essentially arguing the Government's case rather than its own. Because American Express failed even to identify a relevant market failure, the court's analysis of the first justification correctly ended at this point. ${ }^{316}$

As its second justification, American Express (like many antitrust defendants) claimed its restraints were necessary to prevent free riding. ${ }^{317}$ The court's analysis again began with step one: identifying the particular alleged cause of market failure. This time, the cause was valid. As the court explained, free riding can cause market failure "even in purely competitive markets." ${ }^{318}$ Thus, the court proceeded to step two.

At step two, the court assessed whether the relevant market was, in fact, subject to such a failure. Free-rider problems occur only where a particular business model or strategy creates some positive externality that can be captured by a third party. Thus, the court analyzed whether American Express's business strategy actually created some positive externality that merchants could have taken advantage of without paying. American Express claimed to be concerned about merchants free riding on its "useful advertising products" and "other market intelligence products." 319 But because American Express could have-and sometimes did - charge merchants for these services, there was no externality. ${ }^{320}$ Where the ride is not free, there is no free-rider market failure. As a result, the district court correctly rejected the second proffered justification. ${ }^{321}$

312. Id. at 233 .

313. Id. at 228 (citing NCAA v. Bd. of Regents., 468 U.S. 85, 116-17 (1984)).

314. NCAA, 468 U.S. at 87,117 ('[P]etitioner forwards a justification that is inconsistent with the basic policy of the Sherman Act.").

315. In particular, the allocative inefficiency of such an arrangement is readily apparent, though a reduction of dynamic efficiency is also possible, perhaps likely.

316. American Express, 88 F. Supp. $3 \mathrm{~d}$ at 231-32.

317. Id. at 225 .

318. Id. at 234 .

319. Id. at 235 .

320. Id. at 236 ("Where, as here, payment is possible, free-riding is not a problem because the ride is not free." (quoting Chi. Prof'1 Sports Ltd. P'ship v. NBA, 961 F.2d 667, 675 (7th Cir. 1992) (Easterbrook, J.) (internal quotation marks omitted)).

321. Id. at 235-36. In an unfortunate coda, the U.S. Supreme Court made a hash of things on appeal. Ohio v. Am. Express Co., 138 S. Ct. 2274 (2018). Justice Thomas, writing for a slim majority comprising the Court's more conservative wing, advanced the claim that American Express's contractual restraints "actually stem negative externalities." Id. at 2289. 
The structured, three-step framework for analyzing justifications can greatly improve antitrust analysis. It offers clear guidance, increases rigor, and improves accuracy. Employed properly, it streamlines litigation, saving plaintiffs' and defendants' time and money. By avoiding the need to re-litigate erroneously decided cases, it also conserves judicial and societal resources.

\section{CONCLUSION}

Understanding procompetitive justifications is a vital task for a modern antitrust enterprise dominated by the rule of reason. The flexibility offered by the modern rule of reason is generally viewed as beneficial. But flexibility without guidance is chaos. Forty years of confusion is long enough. The task at hand is urgent; the way forward is clear. By injecting much-needed rigor and coherence, the market-failure framework represents a vast improvement in antitrust decision-making.

According to Thomas, a merchant's encouraging customers to use a lower-cost form of payment would cause them to be less likely to use American Express cards at other merchants. $I d$. But an "externality" is some effect of production or consumption activity that is not directly reflected in the market. See PINDYCK \& RUBINFELD, supra note 292, at 645. Even in Thomas's rather far-fetched version of events, no negative costs escape the market; there is no externality. Instead of alleviating a market failure, the restraints (as noted above) actually caused one. See supra note 315 and accompanying text. 